號 四十六百二第

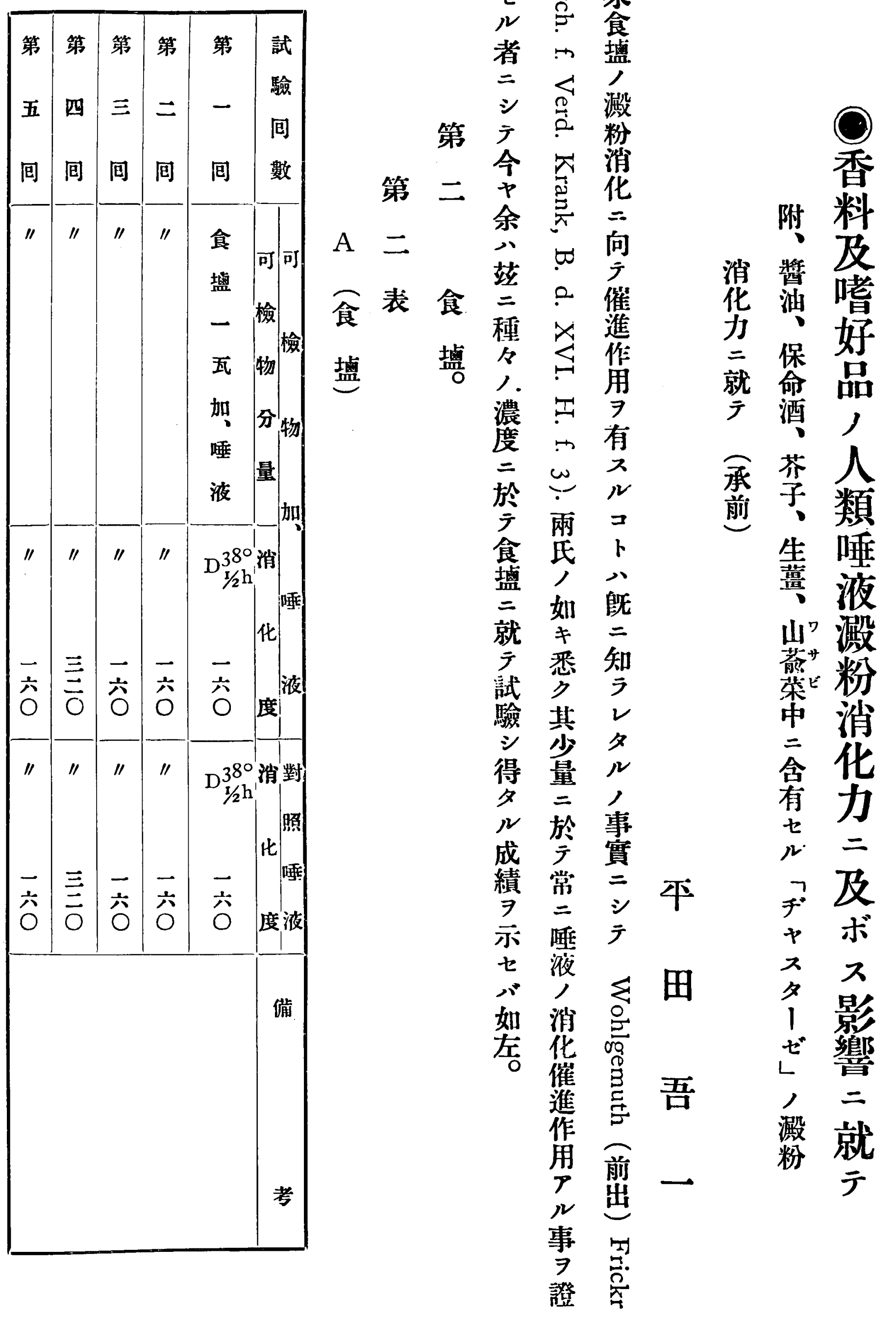

明 元

七点來

? 食

$=<>$

$\overrightarrow{0}$

今 消

香

料

消 獎 攵

化 油咟

二保好

就命 口

濃 开

度有

$=\omega \pi$

广兩

盐, 八

二 如 既

夜

就 キ

厂 悉 知

試クラ

驗 其 2

シ 少 タ

得 量 ル

夕 $=$,

於事

成 $\overline{\text { 實 }}$

績常三シ平学及

示㕰 テ

ホホ

セ液 \&田

如消完 


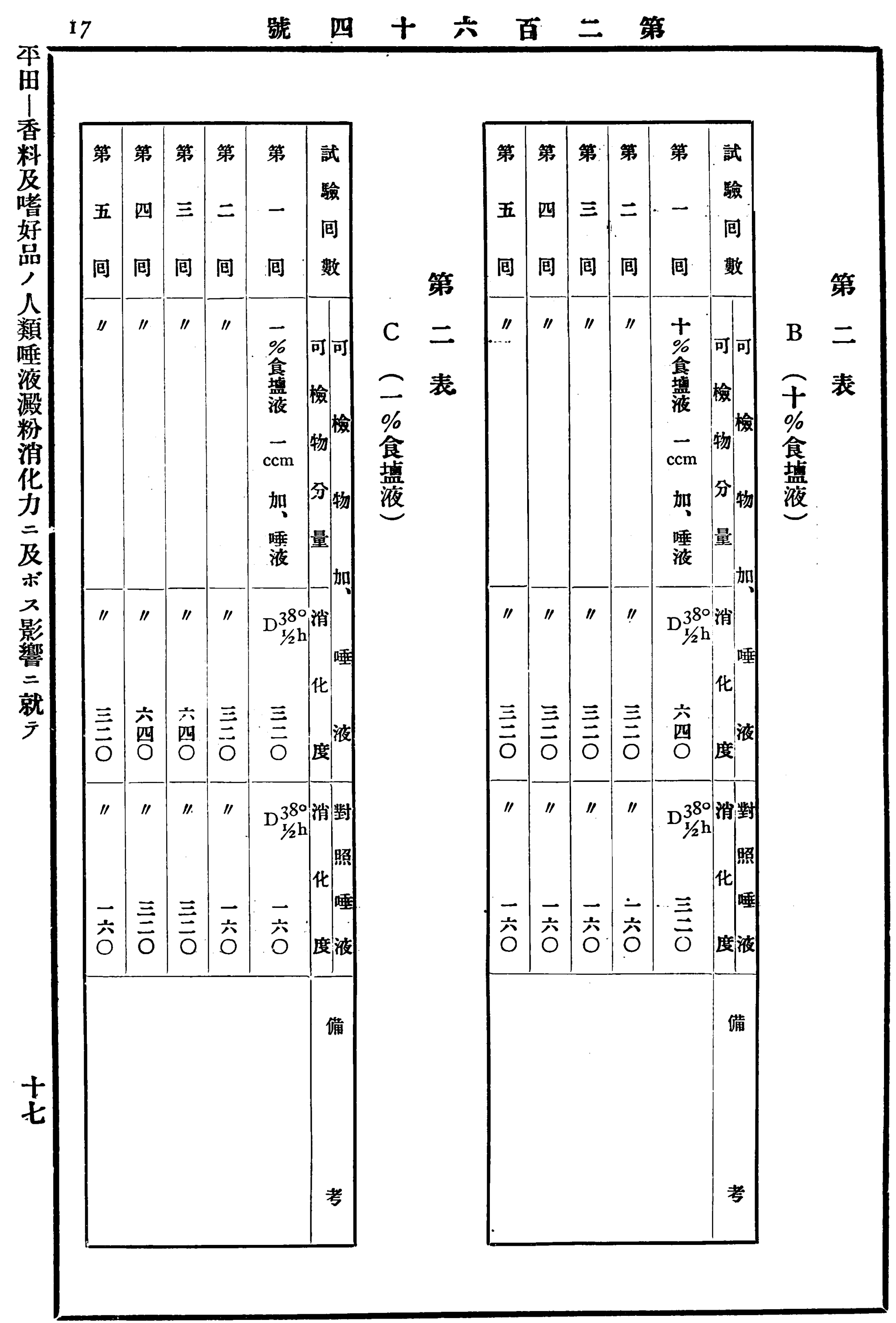


四土音戛二第

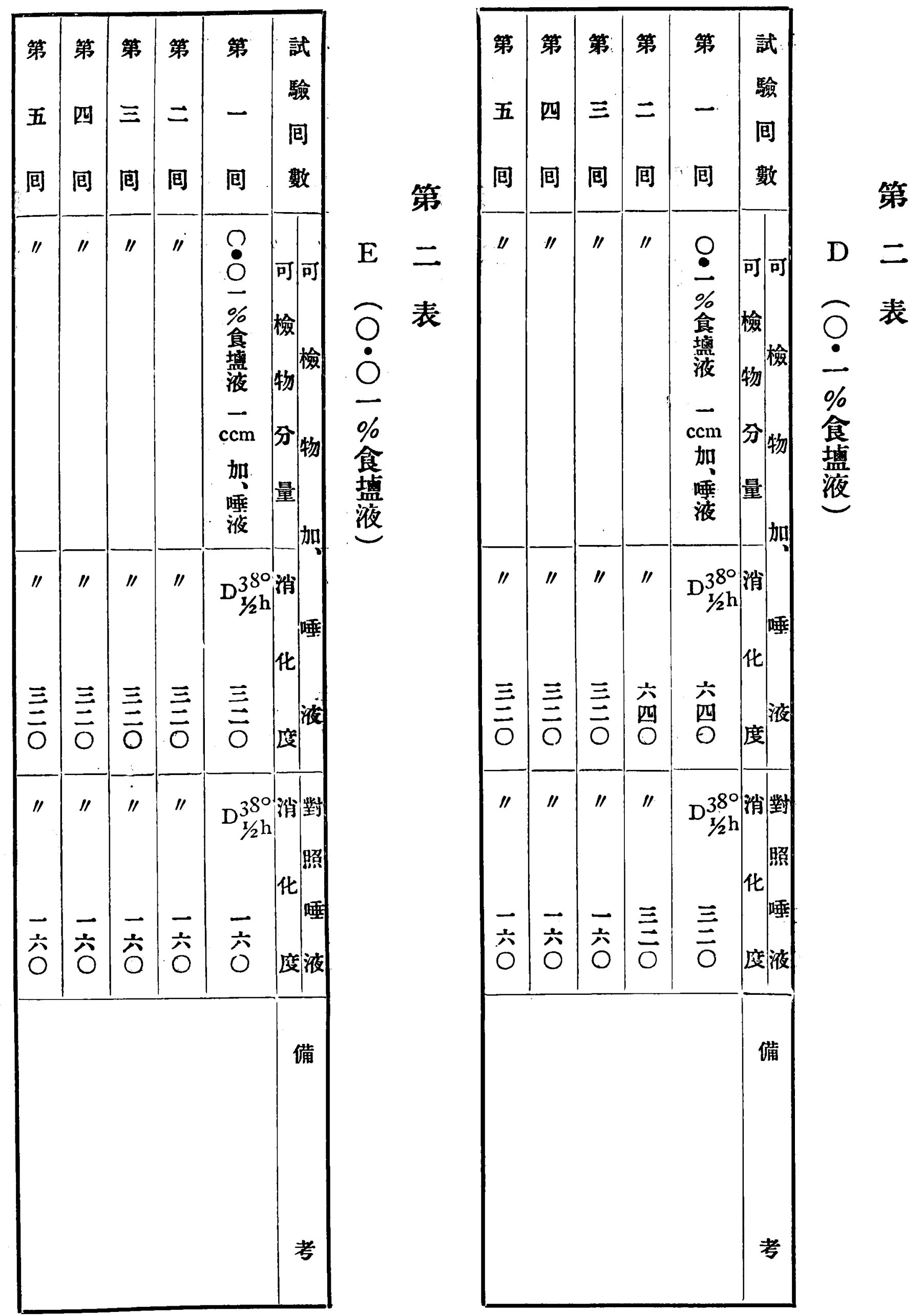


號四十六百二第

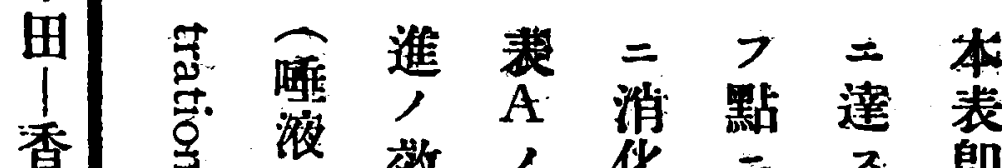

㤩液效, 化二

及 向ナ示少於心手

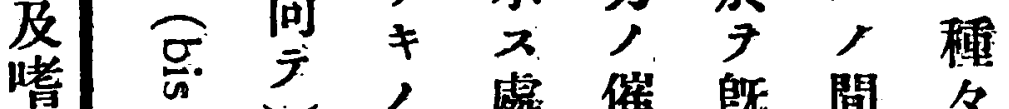

好 洼ミ處催既間今,

品

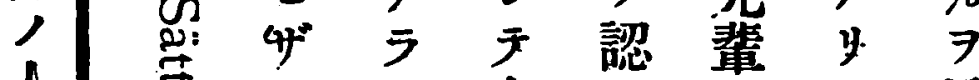

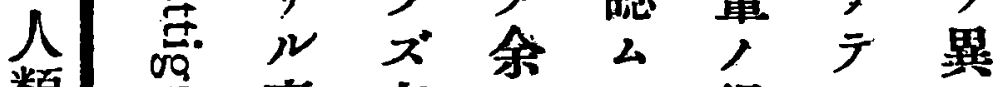

類 亭事亦公得心要

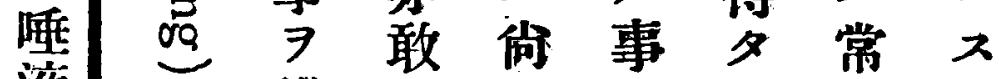

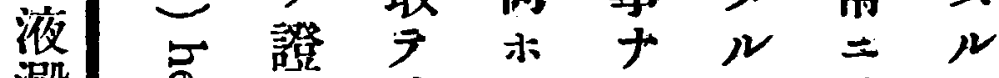

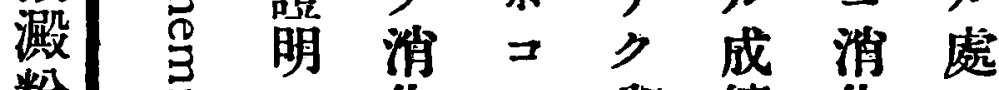

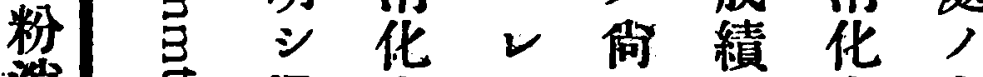

消 得为以本占食

化思多, 上十相盐

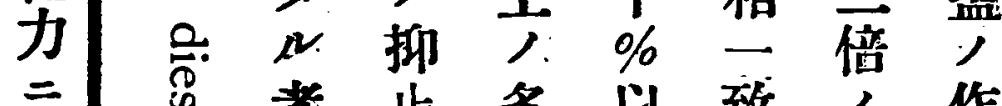

若者止多以致, 作

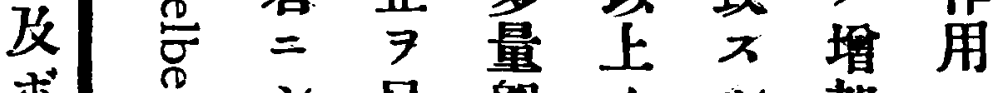

少 シ 呈師, 加二

不影 テ ス 千 濃 事 7 就

影 則 $N$ 二厚 $\exists$ 現

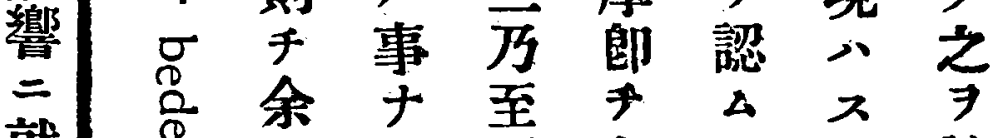

就 备, 丰四食卜者試

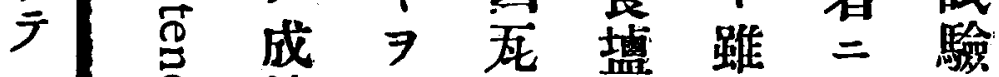

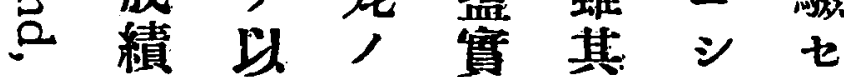

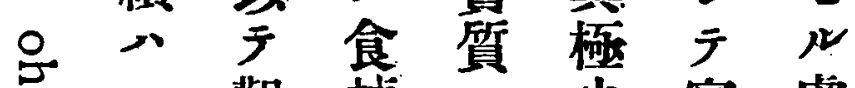

志山觀 盖省實處

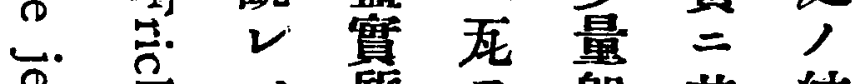

余 代質 $\ni$ 郎 其 結

今 比 7 加 千少果

。前 㜞 加 $2 \bigcirc$ 量 二

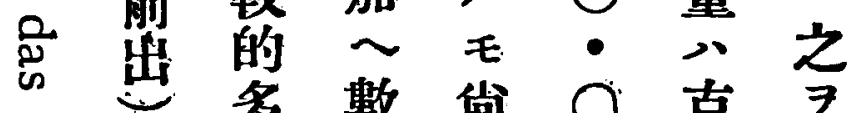

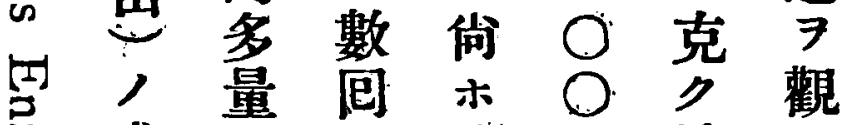

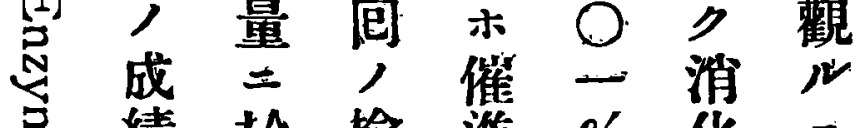

马績 於 檢 進 \% 化 二

+

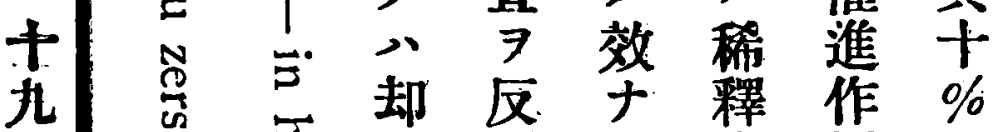

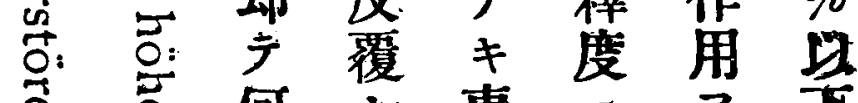

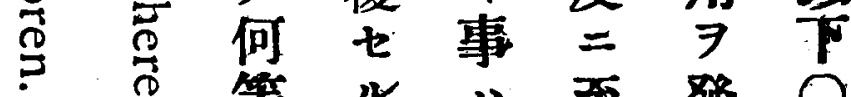
等 $几$ 至唹 0 1 只 $㇒$ 既 y 起 二府作獨三广不

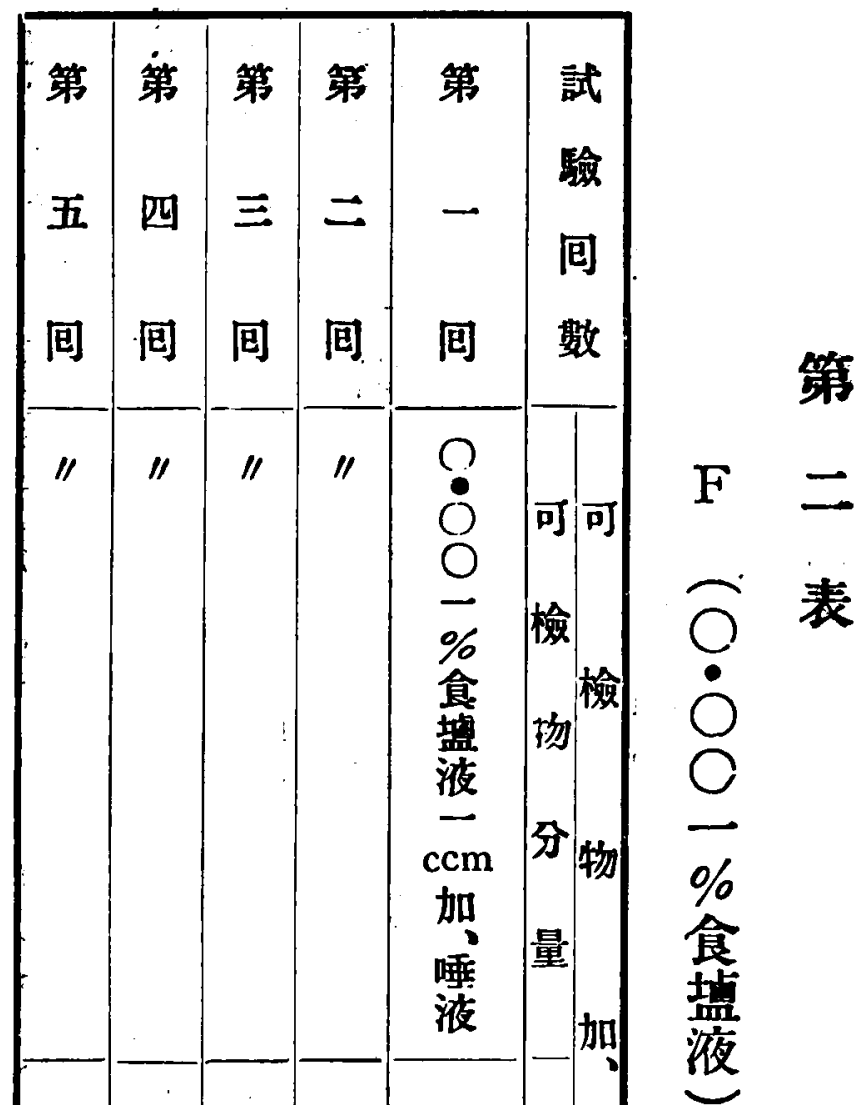

第

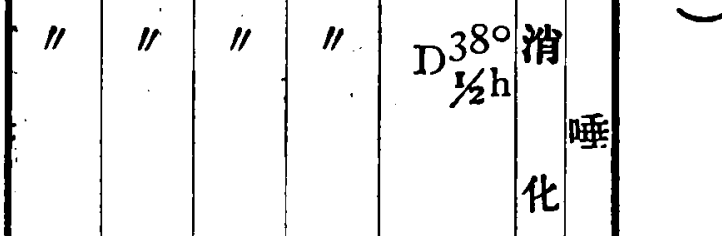

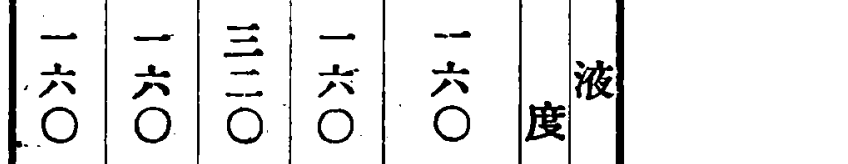

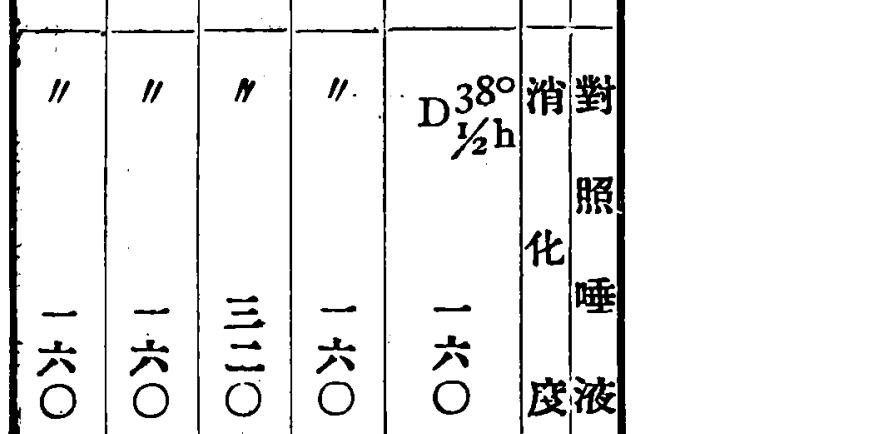

相 空用 y 第 几

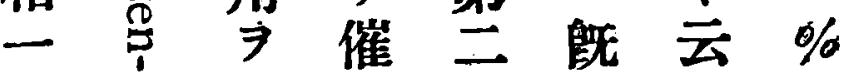




\begin{tabular}{|c|c|c|c|c|c|c|c|c|c|c|c|c|c|c|}
\hline 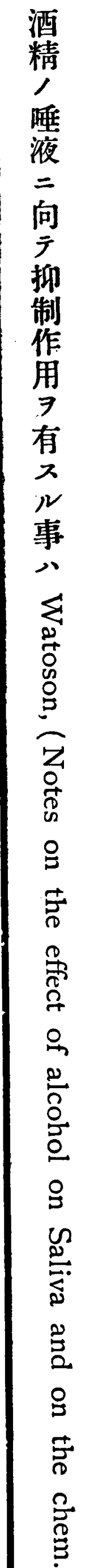 & $\begin{array}{l}\text { 第 } \\
\text { 三 } \\
\text { 酒 } \\
\text { 精 }\end{array}$ & $\pi_{0}$ & 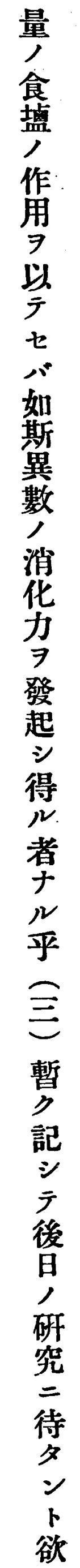 & 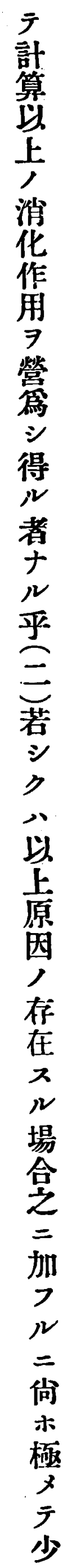 & 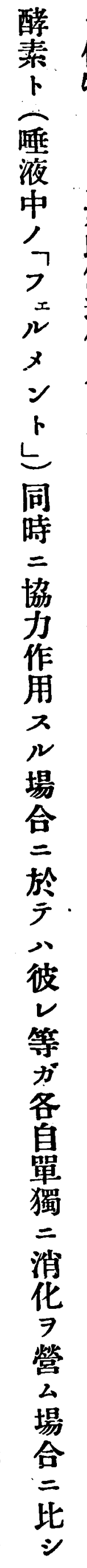 & 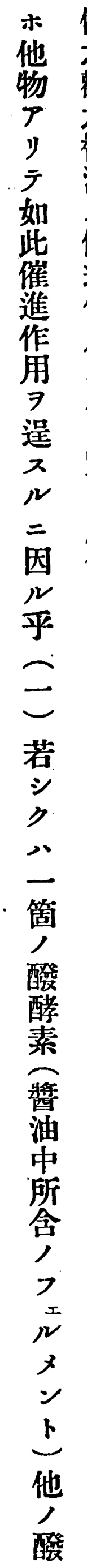 & 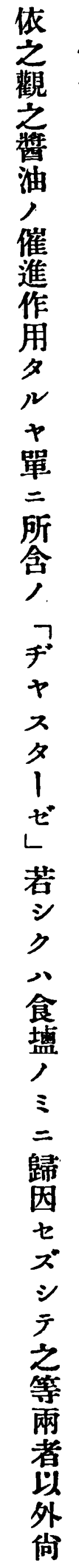 & 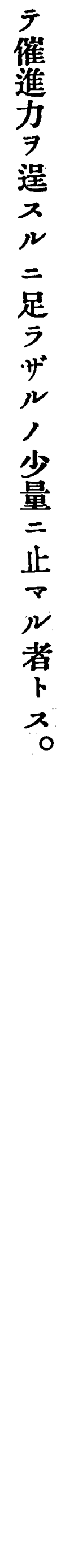 & 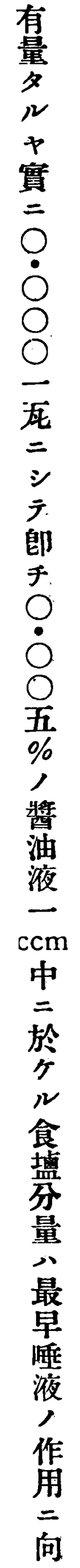 & 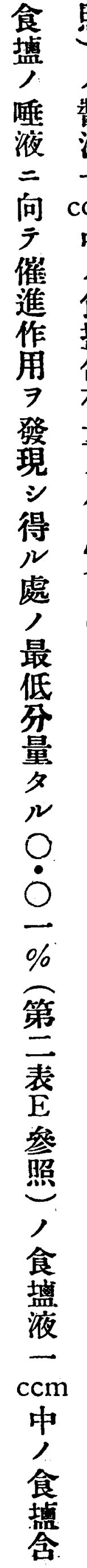 & 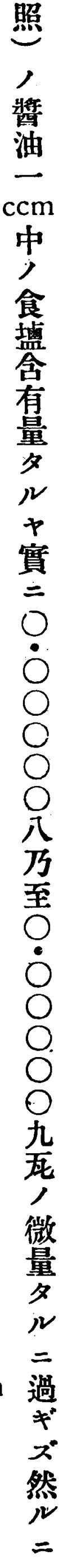 & 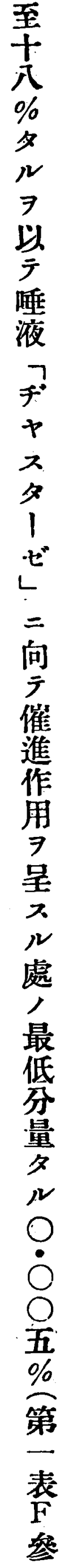 & 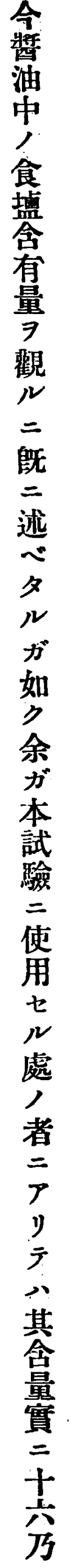 & 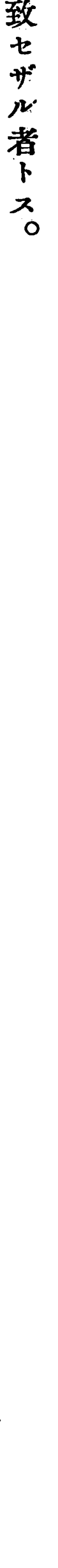 \\
\hline
\end{tabular}




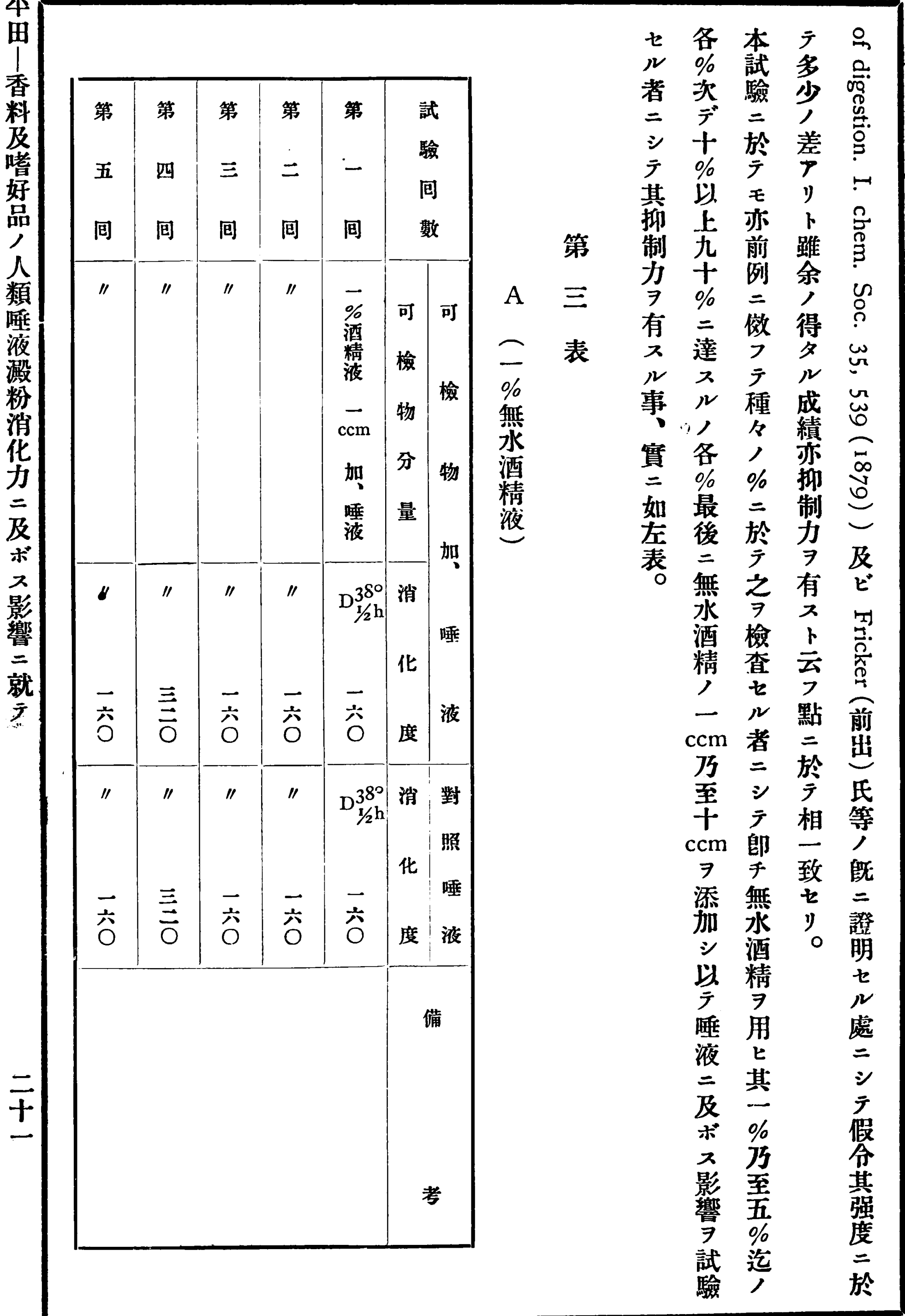




\section{號 四十六百二第}

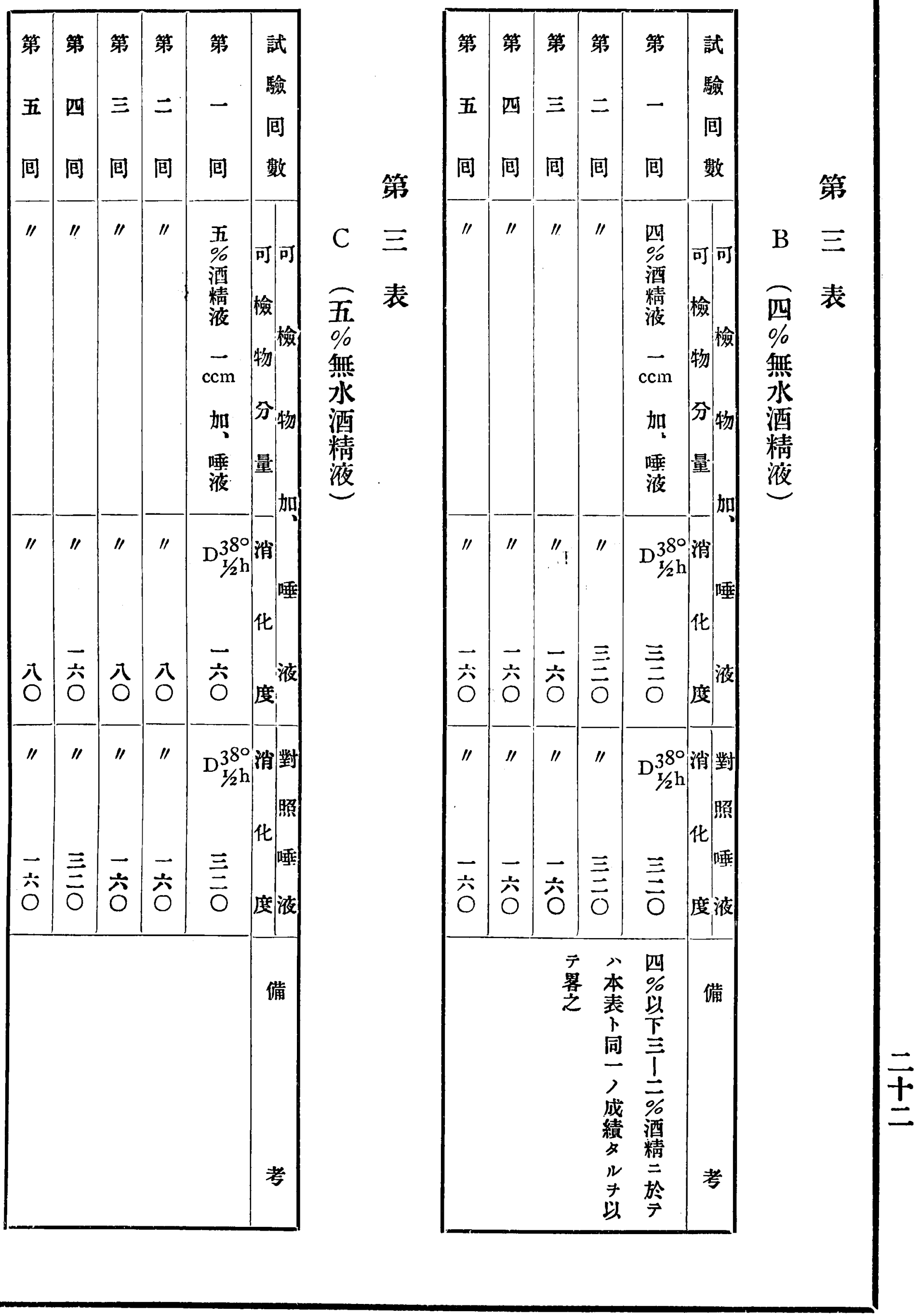




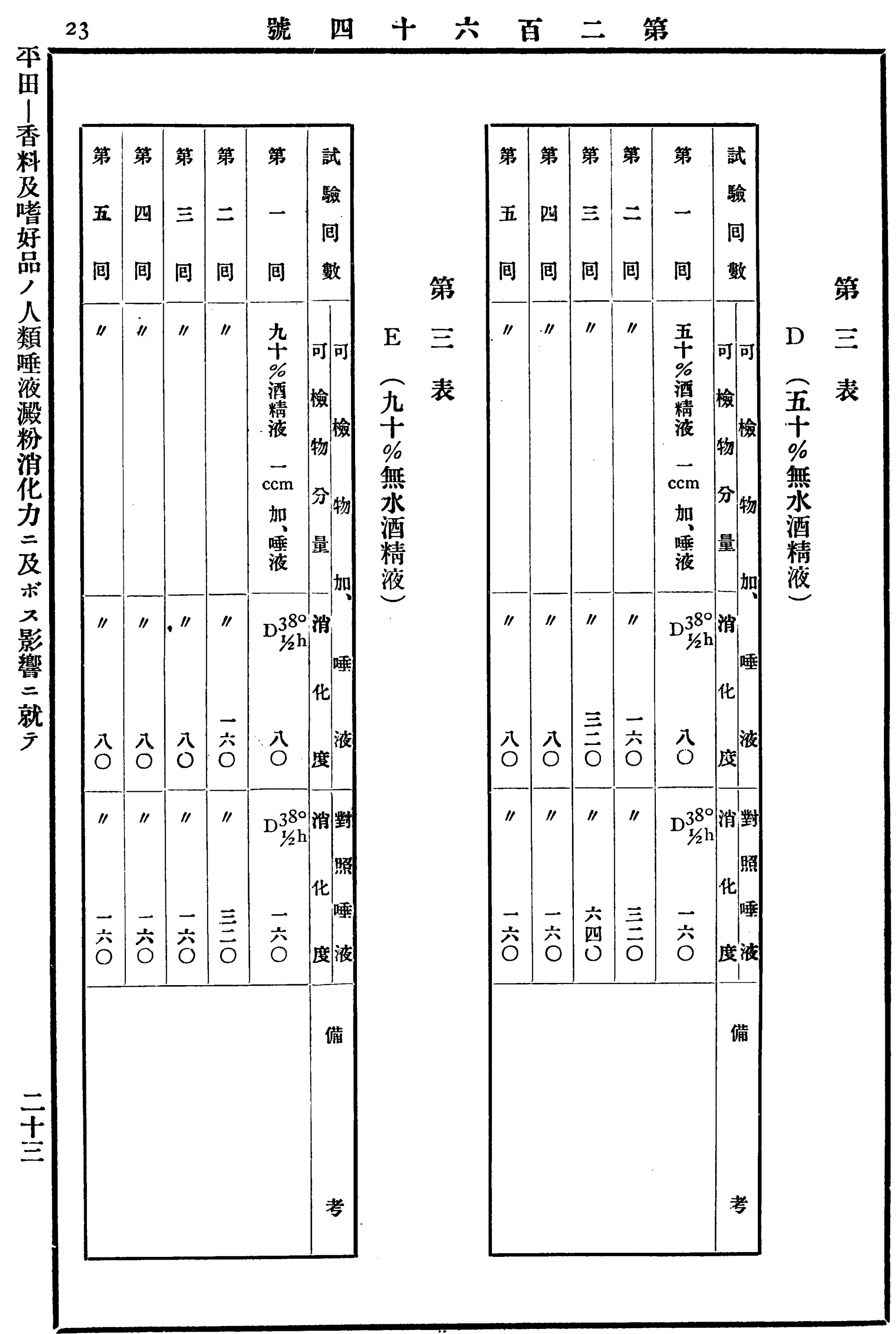




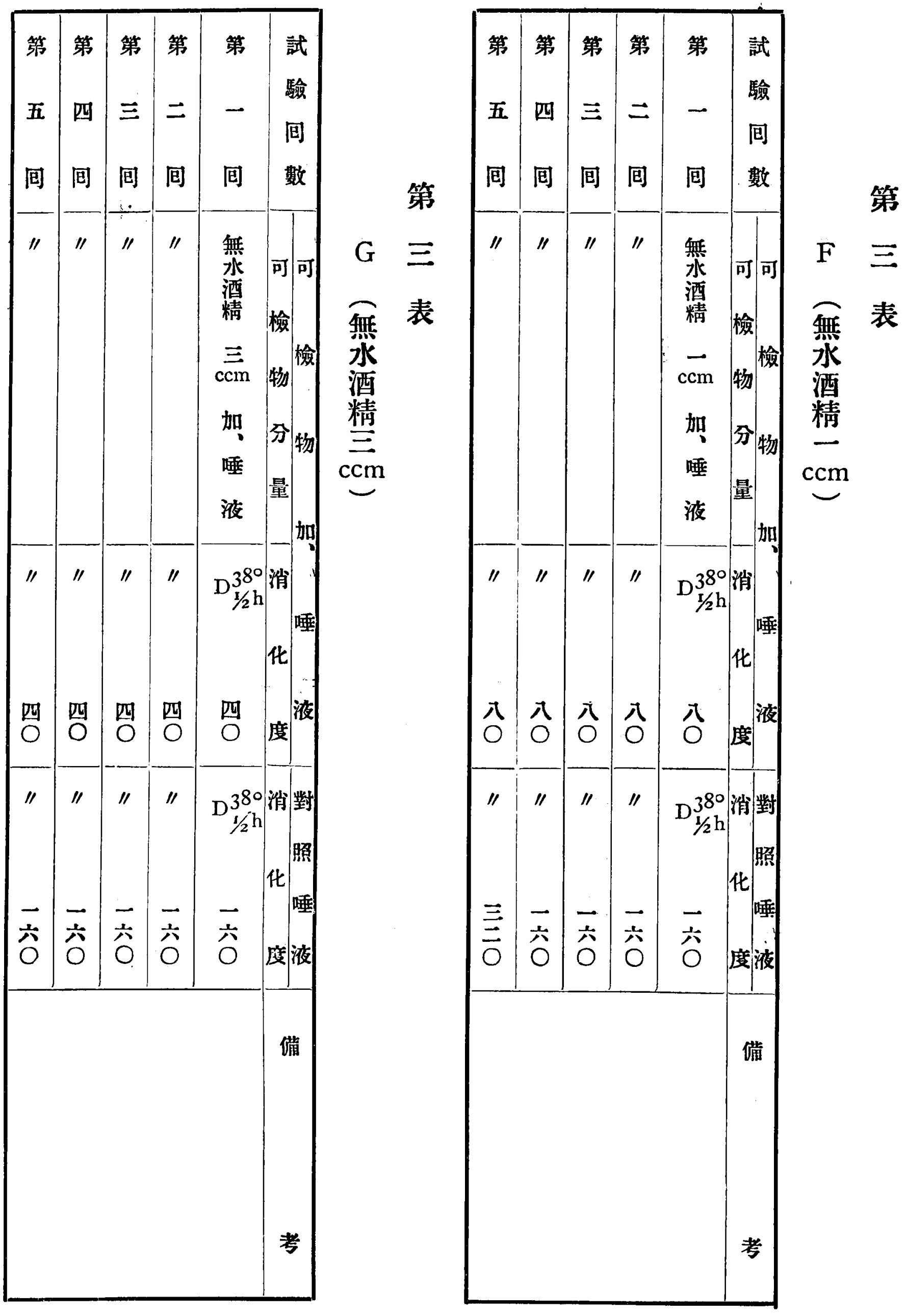


25 號 四十六百二第

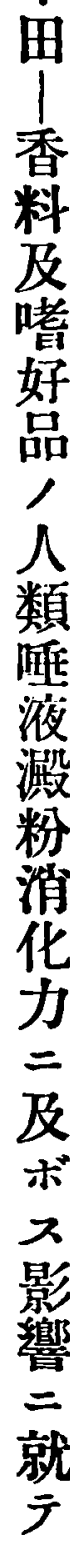

\begin{tabular}{|l|c|c|c|c|c|}
\hline 第 & 第 & 第 & 第 & 第 & 試 \\
五 & 四 & 三 & 二 & 一 & 驗 \\
可 & 回 & 包 & 回 & 回 & 數 \\
\hline
\end{tabular}

" $"$ "

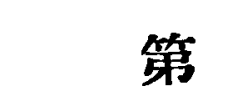

\begin{tabular}{|l|l|l|l|l|l|}
\hline 第 & 第 & 第 & 第 & 第 & 試 \\
& & & & & 驗 \\
\hline
\end{tabular}

回回间间间 數

第

水可可

I $三$

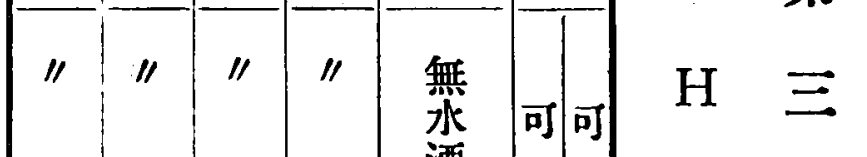

精 檢 無 表

十cm 物 水

加 分物 精

液 量 ${ }^{\mathrm{ccm}}$

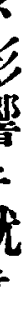

加

" " " " $\mathrm{D}_{1 / 2 \mathrm{~h}}^{380}$ 消

化

五五五

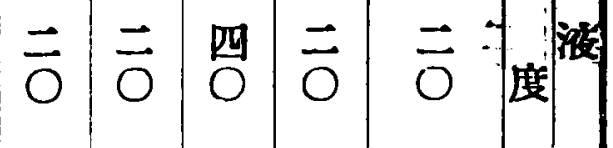

" " " " $\left." \mathrm{D}_{1 / 2}^{380}\right|_{\text {化 }}$

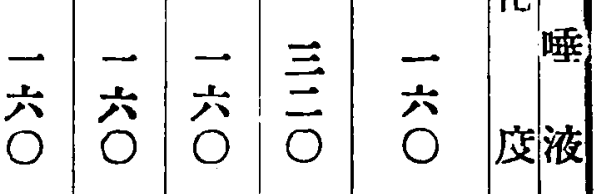

" " " $"$ " $\mathrm{D}_{\mathrm{x} / 2 \mathrm{~h}}^{38^{\circ}}$ 消對

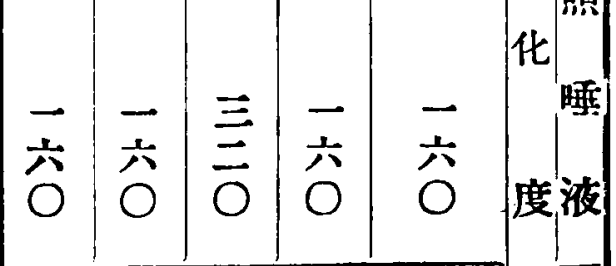

備

備

$\frac{二}{\text { 十 }}$ 


\section{號四十六百二第}

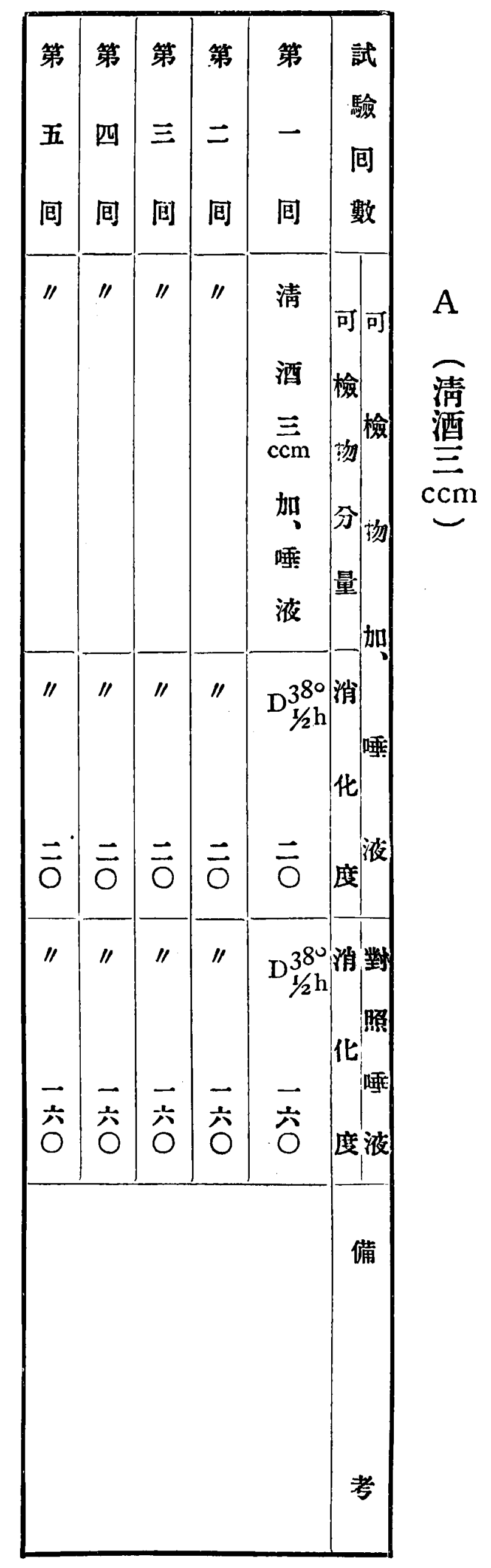

者秎余壞 7 以

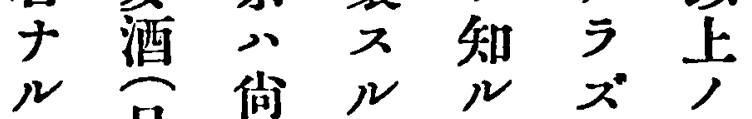
事旦桶者二检 马本諸者足

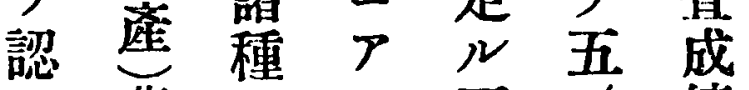

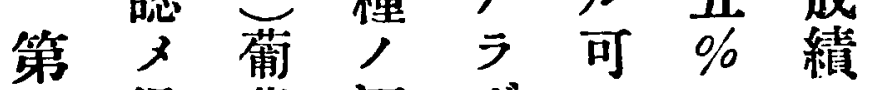
得䔄酒ザシ; 第四夕酒精ル下稠 リ 今 本 有 以 無 $=$ テ 其本物齐水達之 成座二見酒 績 燒 就 精 初 萑見 酒 $\ni$ 酎 テ バーメ ル 順. 其 $\mathrm{O}$ 其 序白作 㧕 $\mathrm{ccm}$ 抑 列酒用制, 制 \% 舉, $\Rightarrow$ 力多作 以 七各檢夕量用上

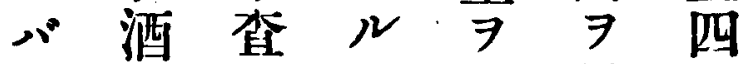
實 精 七 以 呈 \% 二飲 ル 比 テ シ 二 如料二較 シ 之達 左物 獨的 佮 表亦り薄施以ル 夕保弱睡上, 卜 命夕液 濃 程 七酒少 $\bigcirc$ 度度 强八事 ・ 度 例 $\exists$ 五 進 於 二外知方公 於ナル至二小 $\bar{\gamma}$ 可二比決 差 ア 雖 人 り其 第 少 テ 唾 卜他豆一量一液 踓人表三層人 悉 酒 I 向㧕 消 精 參 抑 含照 $モ$ 作 力 制有 0 全 用 $\Rightarrow$ 作物 当 $\Rightarrow$ 抑 用 假 其 遈 制 $\exists$ 命 作 $ᄌ$ ス 有心゙・用ルハ ス清 $\exists$ 者 ル酒破ト 


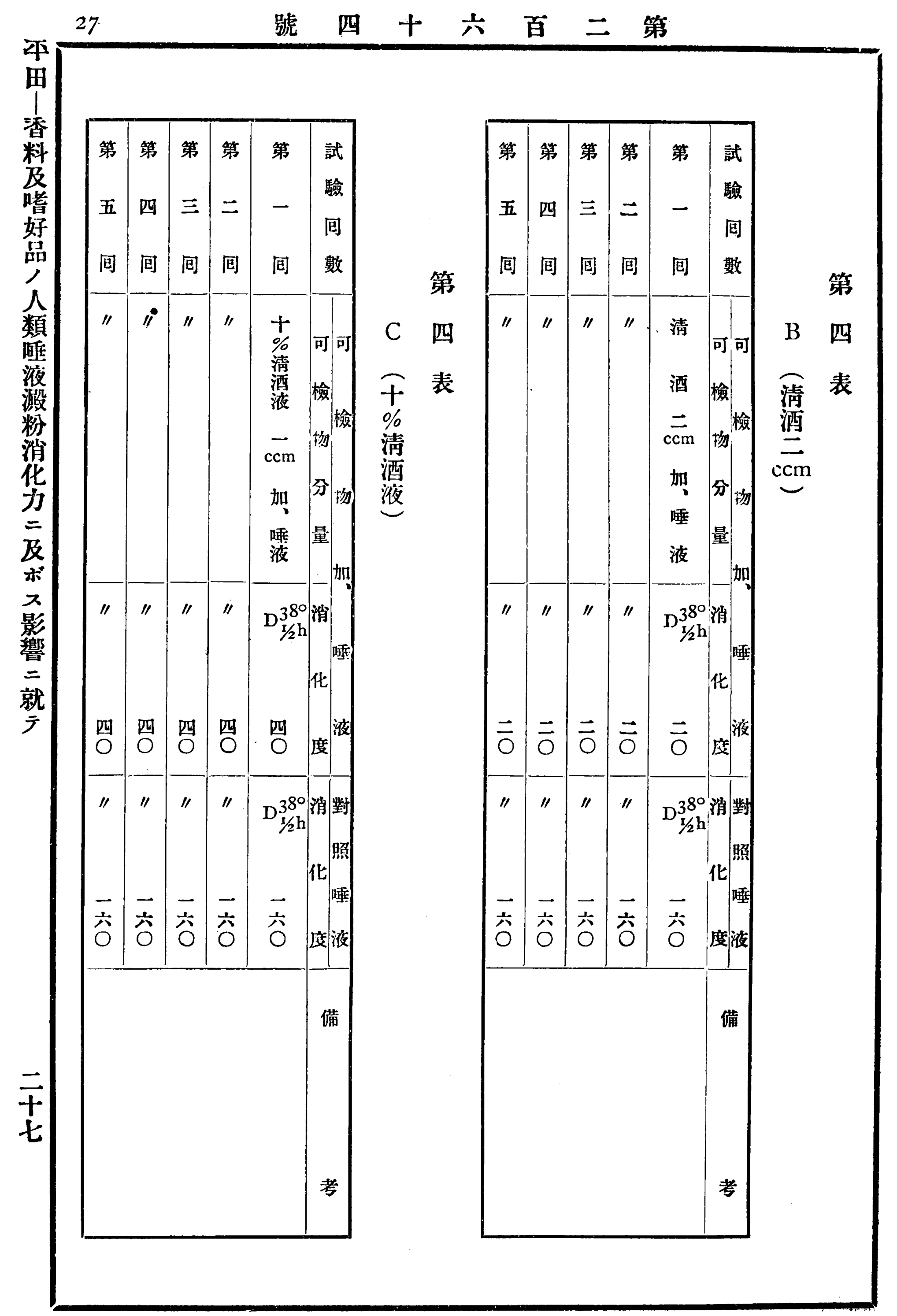




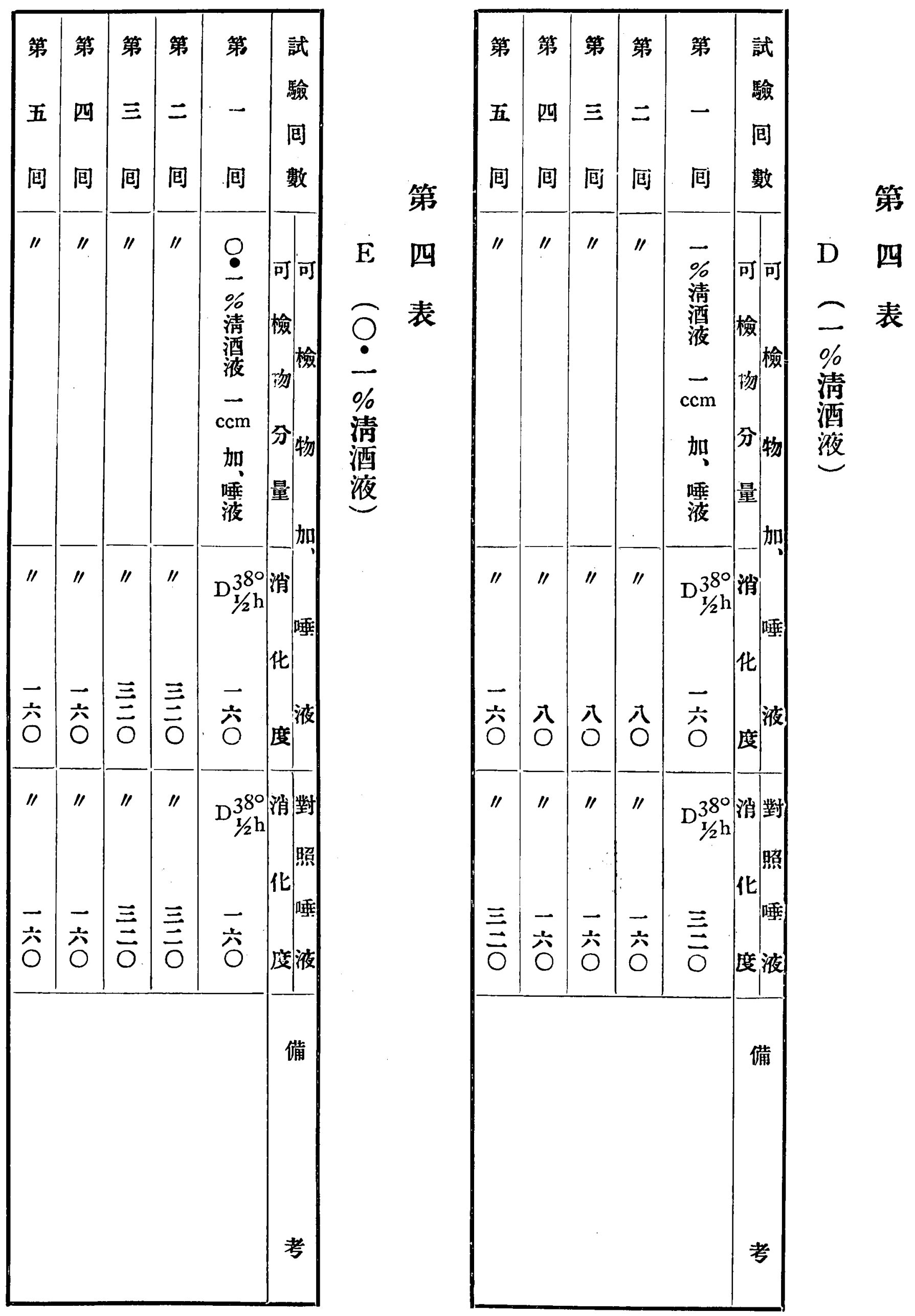




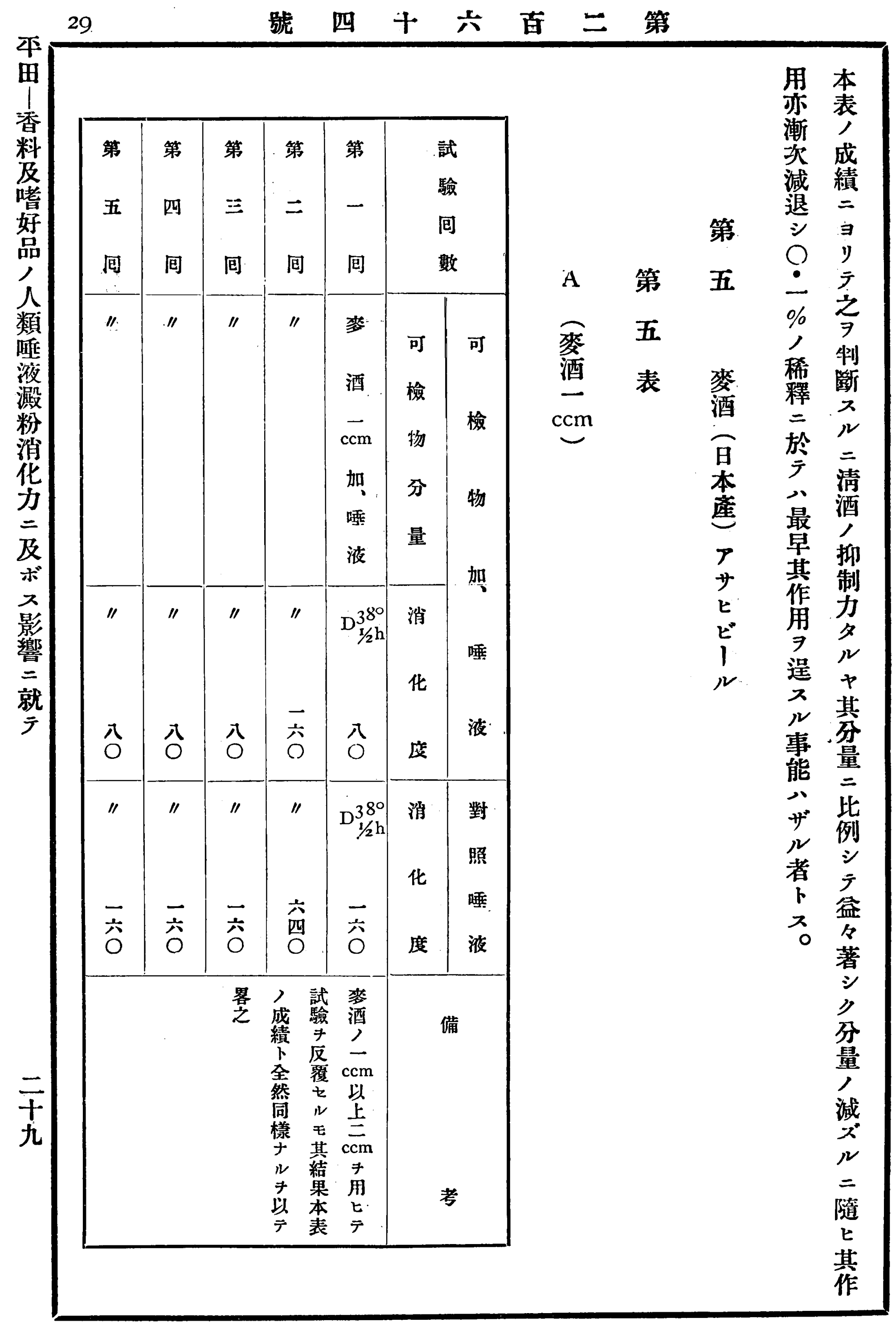


號四十六百二第

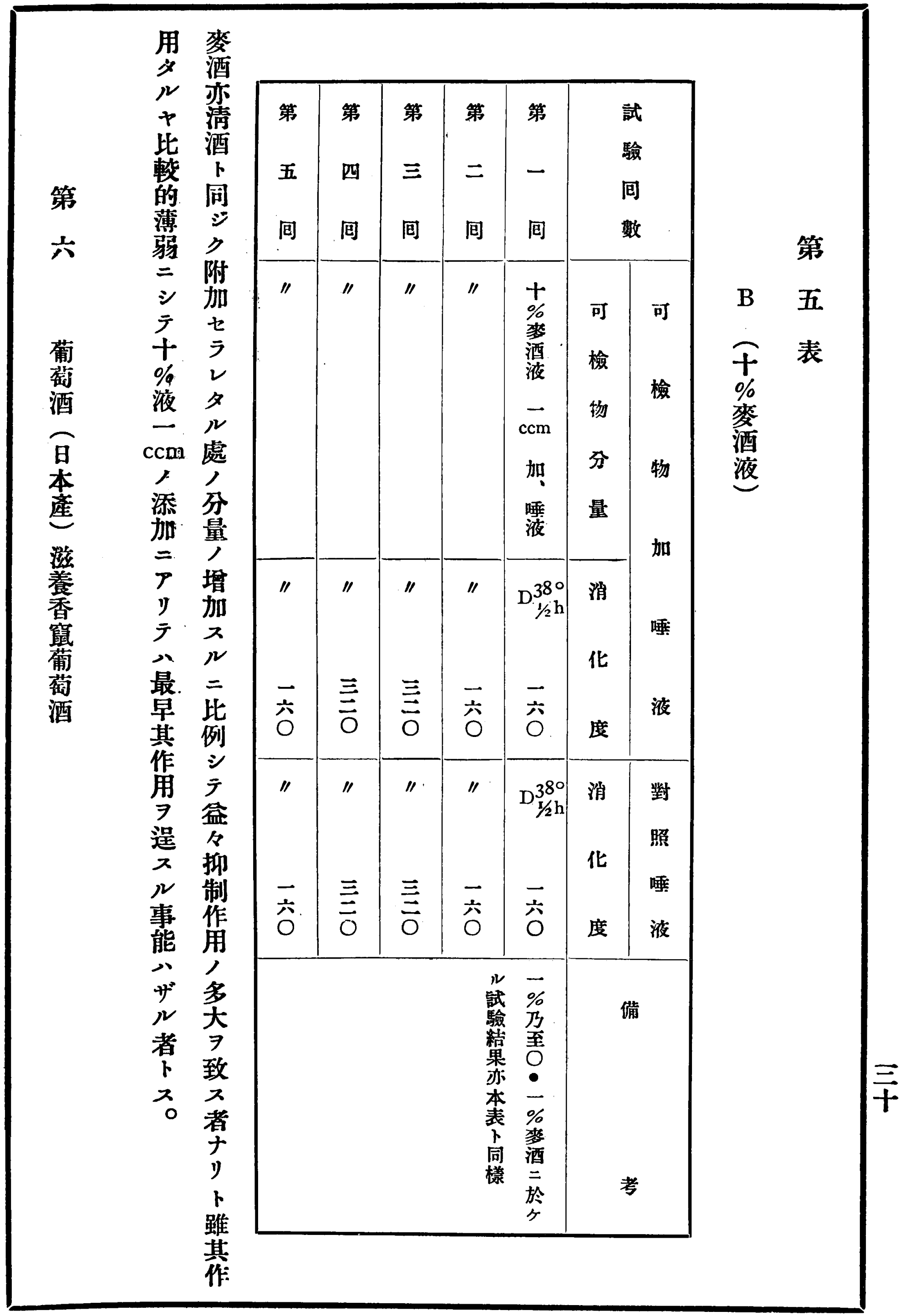




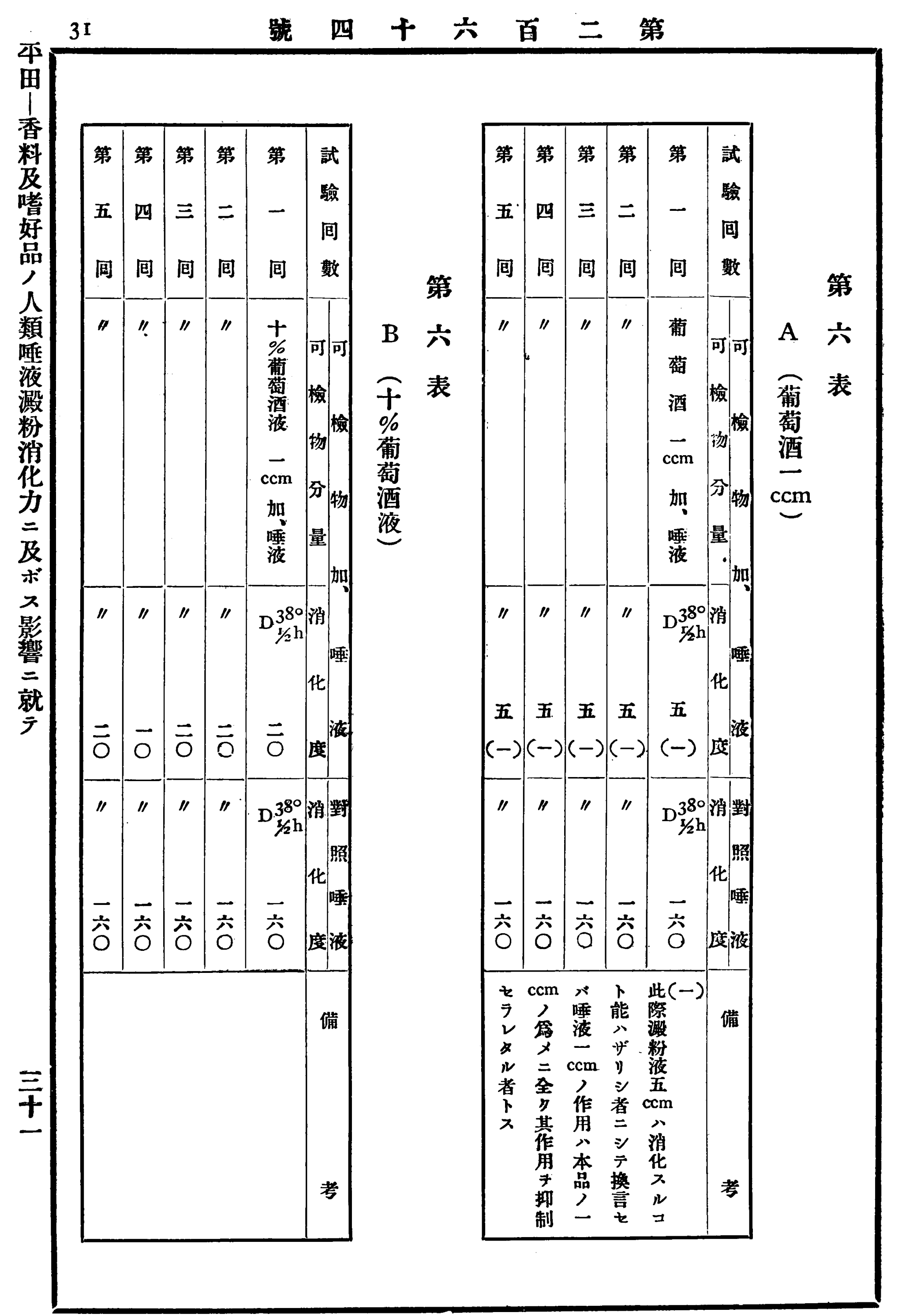


）本於達七間葡

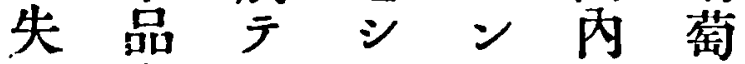

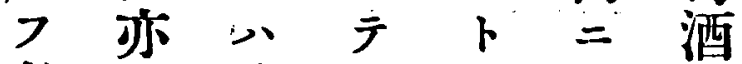
者其策初欲全, 卜附萄又齐抑 天 加酒 テ 烸 塮 制 ○忽 - - 液 制 作 量 $\mathrm{ccm} \%$ ：用 ’ $;$ 澱 一 盡 減 添 粉 $\mathrm{ccm}$ ス ズ加液以者ヤ ル 五上 = 甚 $=\exists \cdot \mathrm{ccm}$ 漸 シ ダ

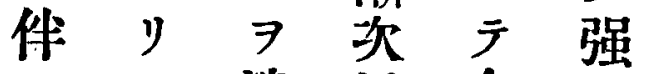
七消增 余大 㧕全化量 心= 制, 然 シ 蒲 シ 作其得 ツ萄テ 用消少、酒之 ，化，之一 減方 7 二 $\mathrm{cm}$ 前 退三確葡 八表

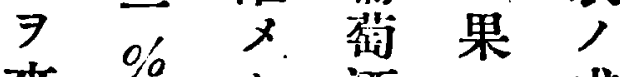
本澱夕酒 少成 ス粉 少 テ 績

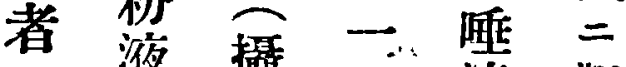
二五后 $\mathrm{ccm}$ 液、整 五 氏 7 氺 于 $\mathrm{ccm}$ 三 加 紋 = 師二十何本 千 對公以 量 品 二 ハ 度 \% ル 試 デー 败 7 声驗, $\mathrm{ccm}$ 一抑走 $\operatorname{ccin}$ 制忽 区用 優 ノ 間覆 $\ni=$ 附盡師七抑，唾 加辛 ル制液 ニル呼 = シ 一 $\Gamma$ 、液 其 得 $\mathrm{ccm}$ リ者二結心， テ $\mathrm{ccm}$ 果者消 八認以活大化 最公下液心少 早 0 , $>7$ 其 芬二 7 三 作 量 $\mathrm{ccm}$ 檢 十 用 $=$ 查哥

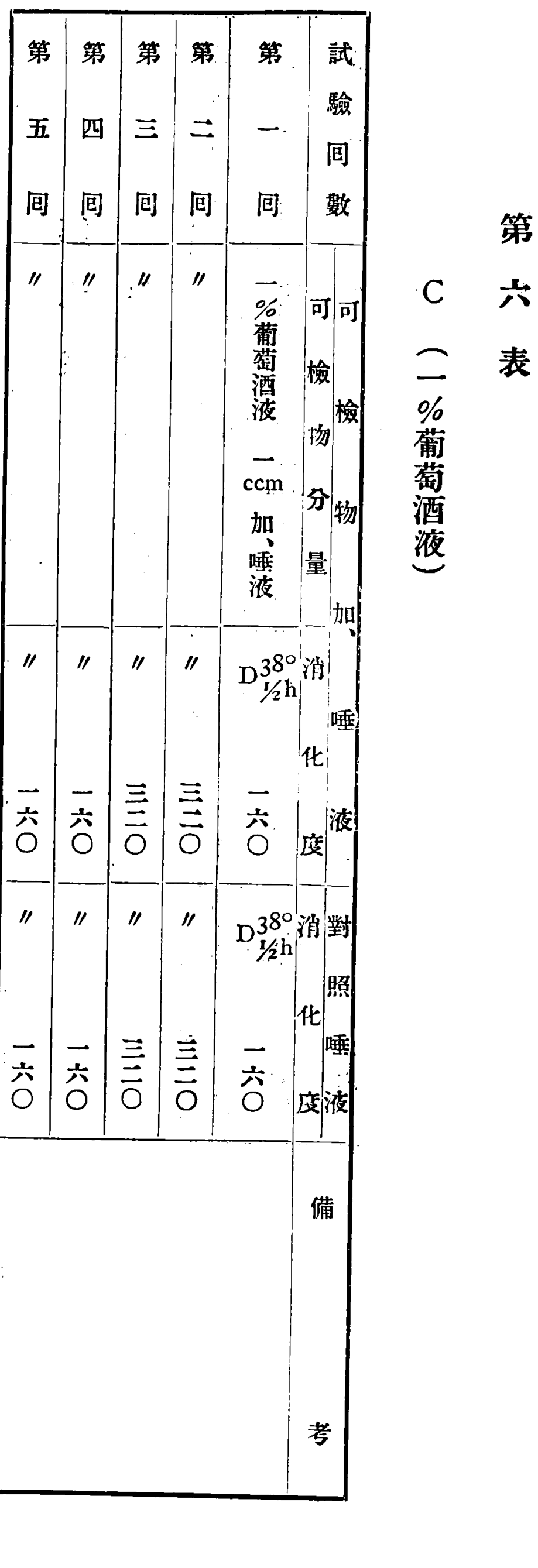




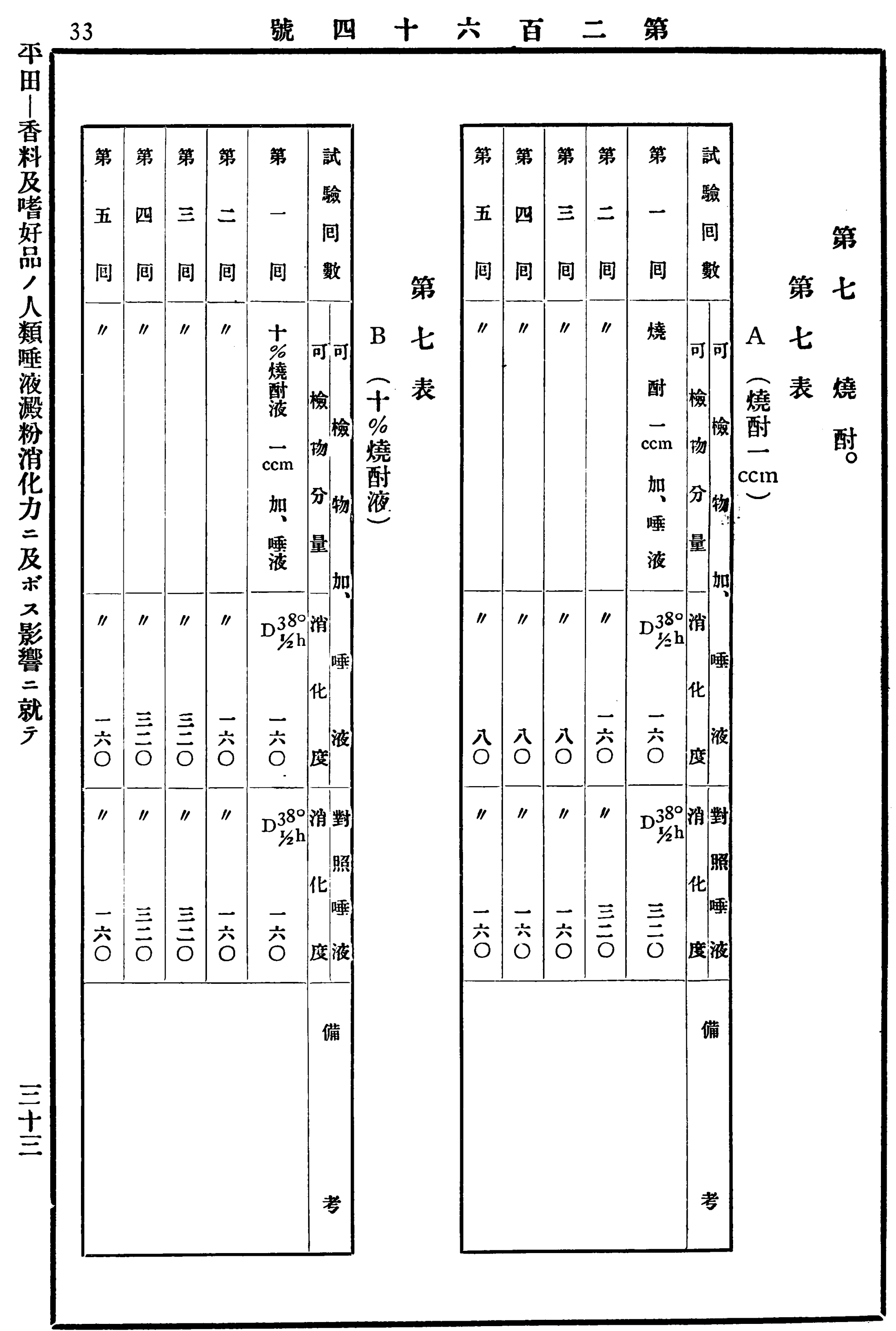


號 四・ 十 六 百二第

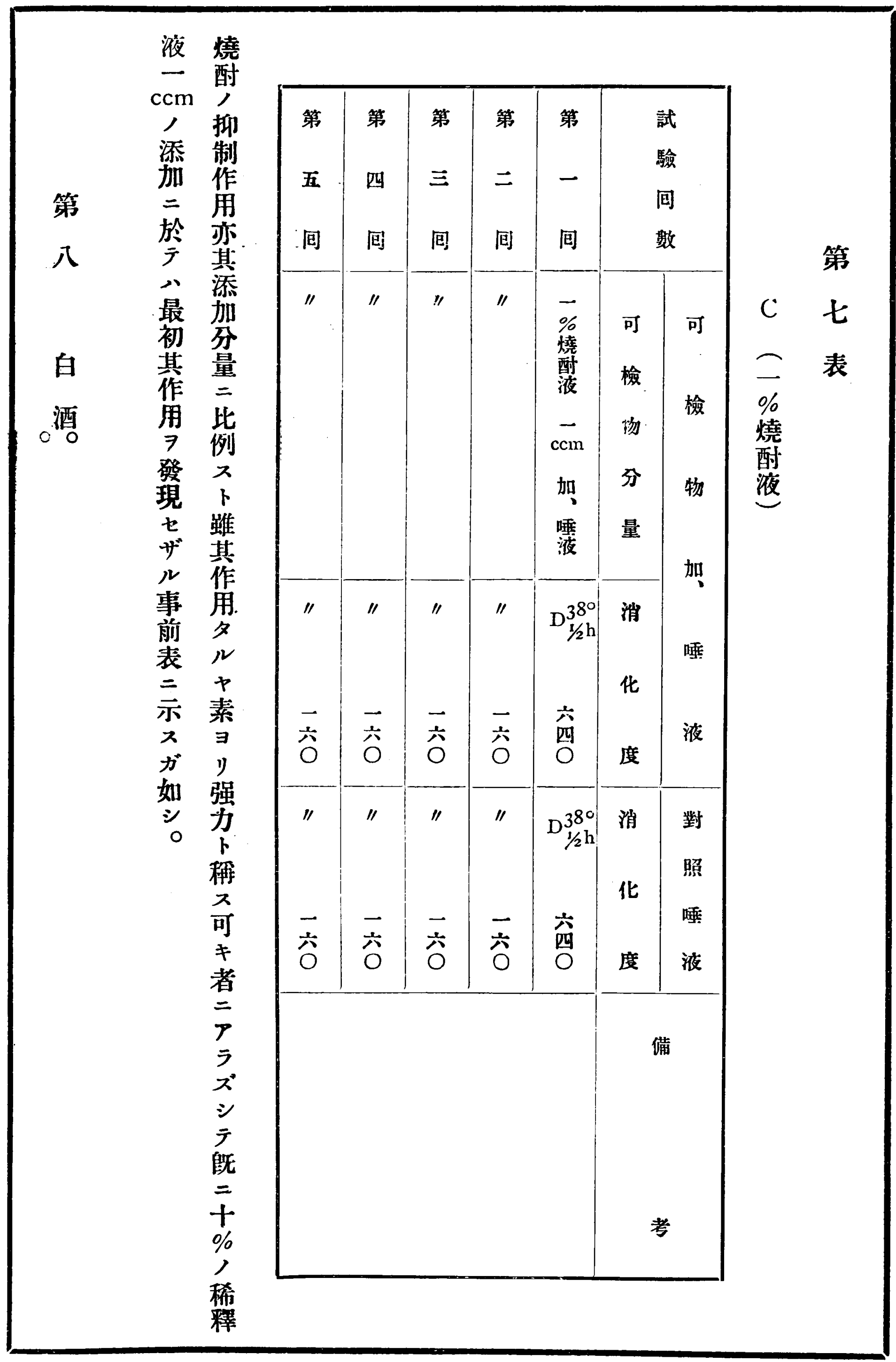




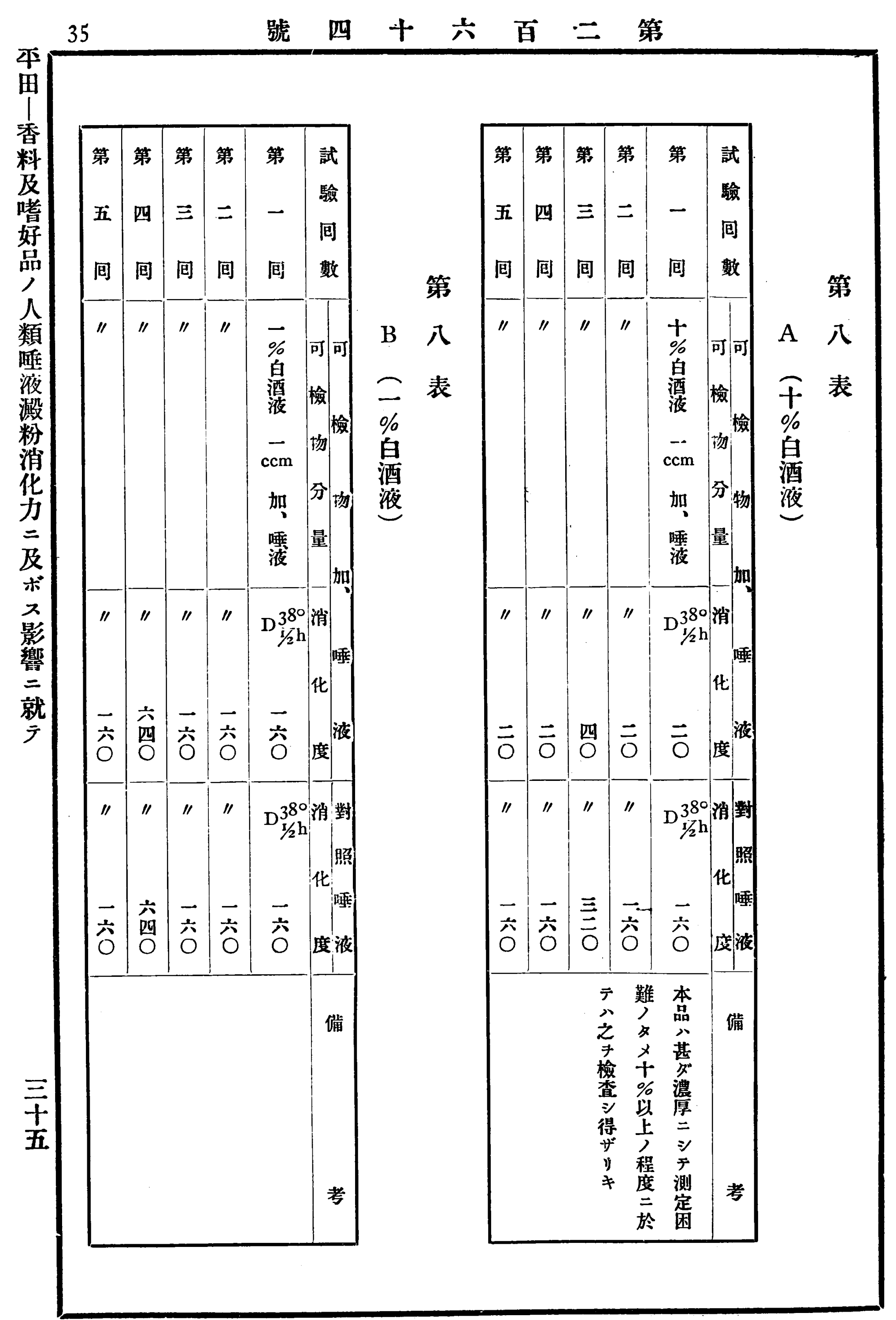




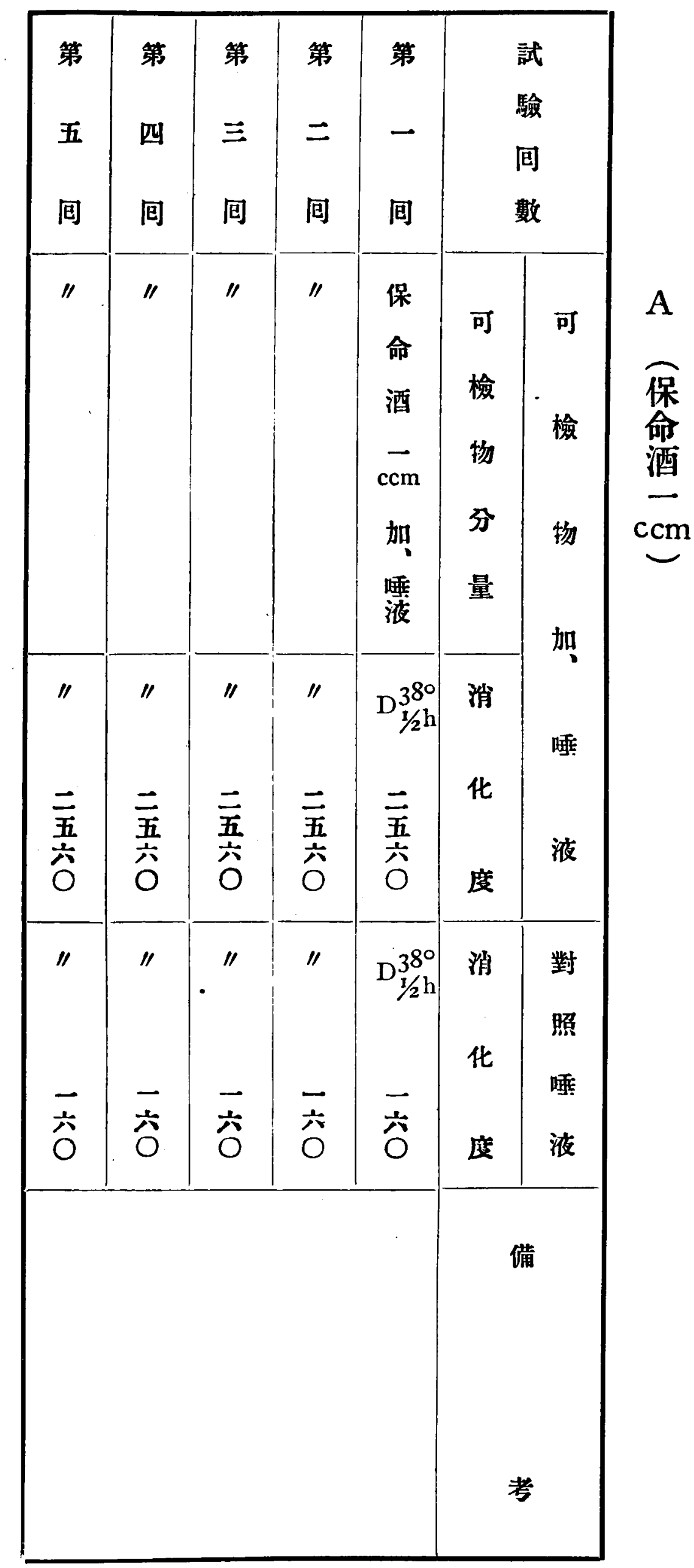

$\%$ 可 白

以 $\neq$ 酒

上 事 亦

之强

分 7 度

量 想

第 二 像 抑

就 ス 制

第九 $ル$ 少

檢 $=$ 皮

A 九 査 足有

シ 2 ス

表保得可ル

$\forall$ シ

命 $\begin{array}{lll}\forall & P & P\end{array}$

酒 $\quad$ 踓 前

事 元 表

承,

遺 本 䠶

喊点 =

卜 示

ス 非 ス

○常 處

$=1$

稠 ス

厚 而

$=$ i

シ テ

テ 本

少品

量 亦

宛 其

之 分

$\exists$ 量

測

定多

入

$\pi=$

$=$ 準

甚

多 テ

困谷

難 今

ナ 抑

ル 制

$\Rightarrow$ 力

以 7

㾏

$+2$ 


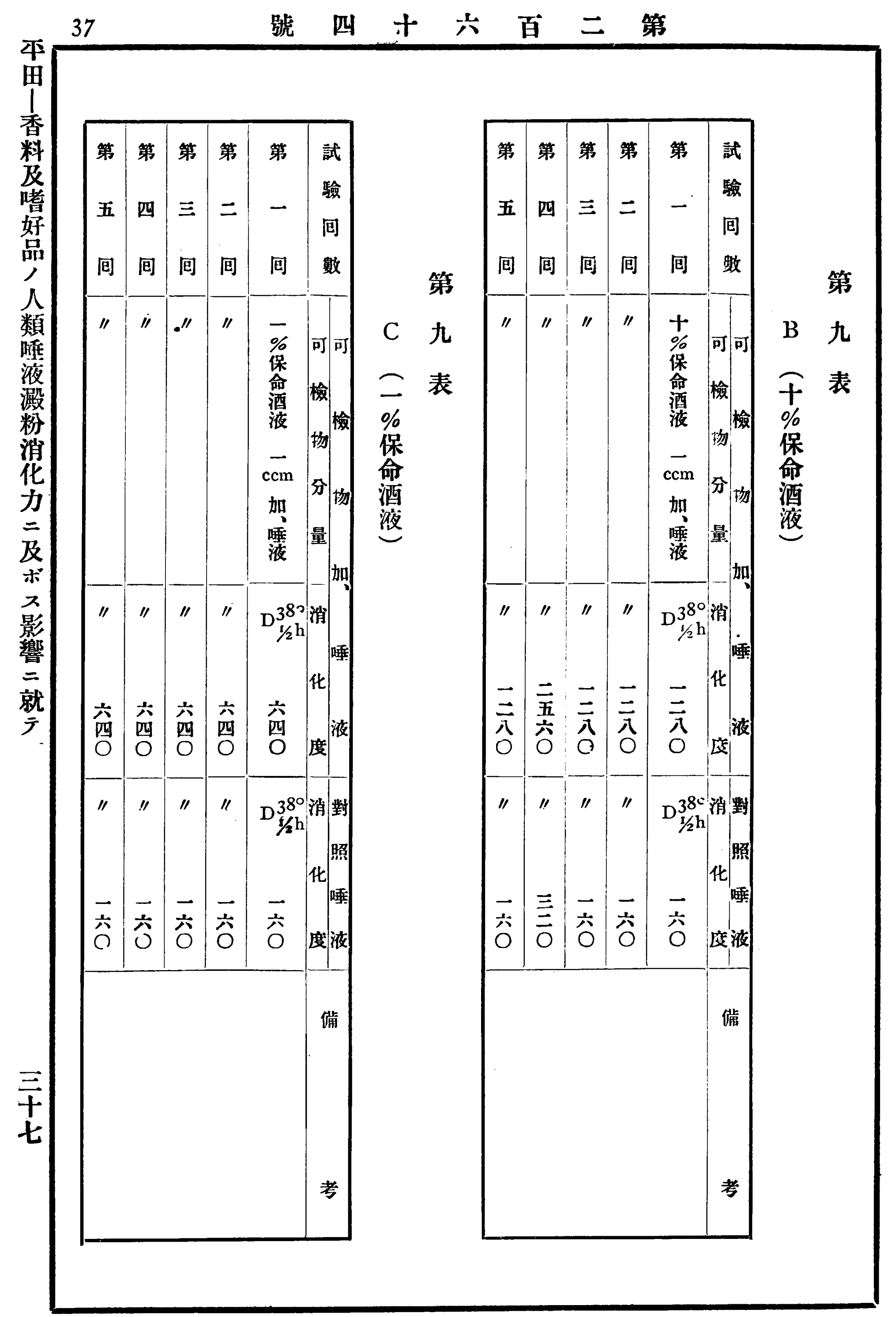


又保 $\mathrm{ccm}$ 郎ノ 夕命 $、$ 疑醬其表 1 酒攝余 7 油作, ゼノ氏 任, 用示 ᄂ 一 三醬 $\neq$ 例夕

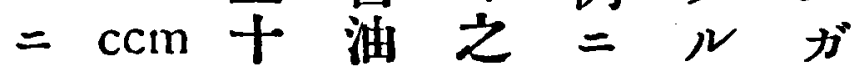
比八刀二ガ 㘕 硠 如 較二度於試ミルク ス十 ル四於 ル人此大り 二時テト結多而酒 實 間 二同果大 $大$ 精 二 =十一余, 濃飲 强前四ノ八催度料 度記時方本進二中 二澱間 式品作比, 於粉二=二用例例 于溶能 $\exists$ 於 7 少外 五液りり テ發 テト 十人一う比起䀂 シ 倍一 \% 其較 スなテ 夕千澱念的 ル 照哑 N ccm 粉有㐱, 加掖 事 7 液 量 量 所 $シ=$ ᄏ消五 7 人謂 $\bigcirc$ 向 認化 $\mathrm{ccm}$ 定 ᄀ或・广 么 ス 7 量 $チ$ 八- 催 ル可消七中本 $\%$ 進 者 $キ$ 化ル品, 作 二者 $シ$ タ 中稀用 シ 1 鲕数 1 釋 7 テス ス包 ゼフ度發 要○事ノレフ二起 ス $\exists$ 試ノ

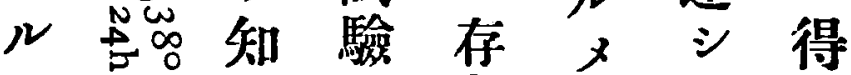
$=-y=$ 在 $ン$ テ 本 8 得 $\exists$ 寻沓者 酒 夕 人今ル常みノテ害 挐之者三得存其三 液 $\overline{\text { 二 }}$ 二保夕在作保

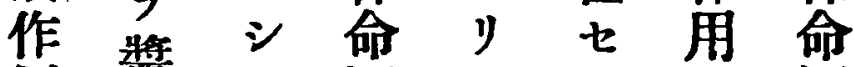
用䙵方酒 $キ$ 酒 二含之,

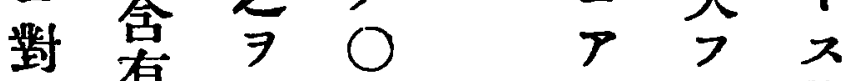
沙改・・者然 テフ ザ算 0 トリ 發ヂ七 $○$ ス而

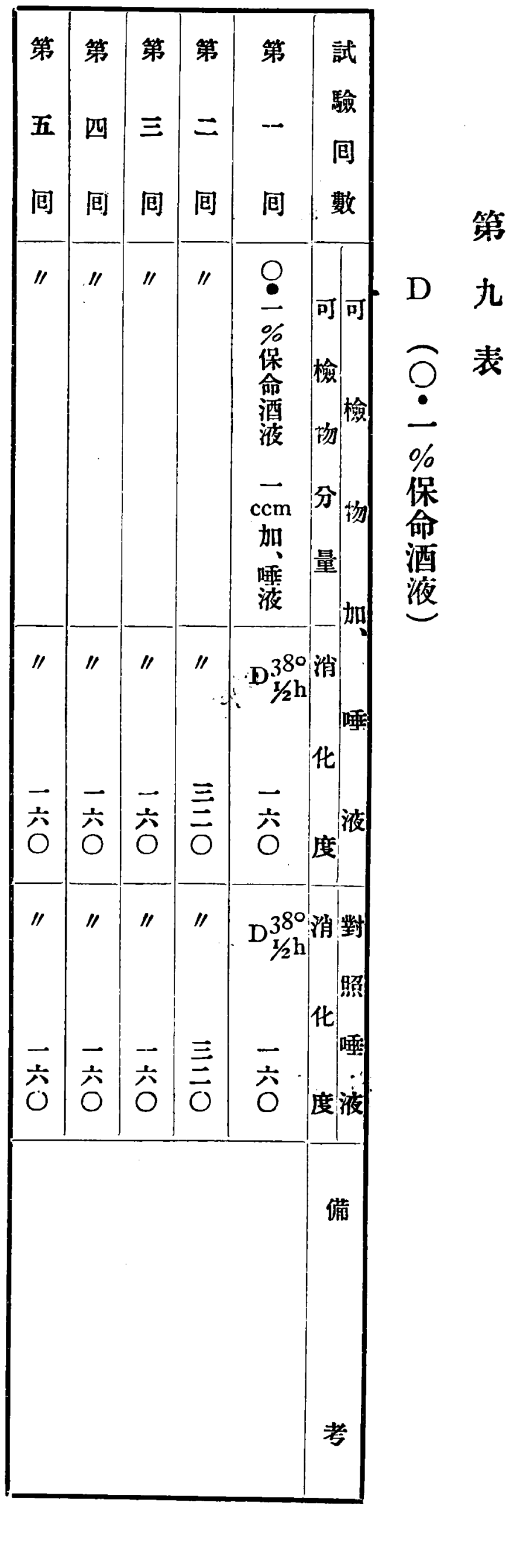


外抑倘催 (一) 作 依消力單七 7 二明合 㴡 二 制

制 东

進 若

料

於 機 前 作 济

之 化

广 能

及

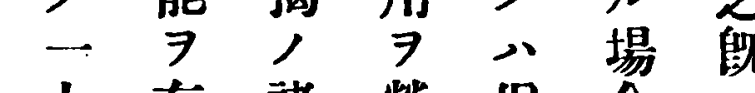

好

大有 諸 營 保 合

觀

化

獨

消

消 $ナ=ル$

關七表么 命 三

係 ザ カ 酒

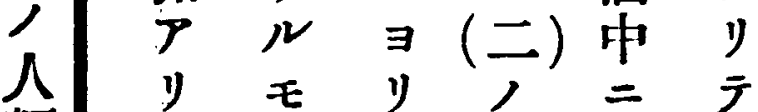

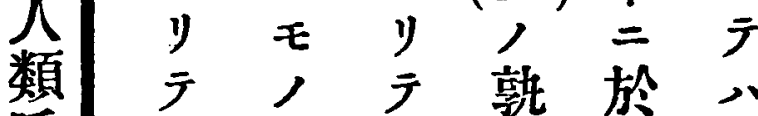

阿

存ナ之斿

㴶

入 シ .

澌

ルト 敬 タ

粉

滑

华

子 不

ᄀ 相

疑然獨少

更

ナ

ル $\rightarrow$ 哂

化化》同卜

及

亦

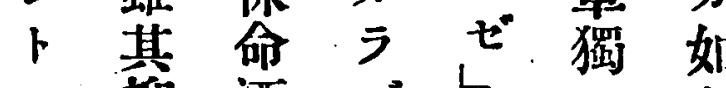

ス抑 酒 $x^{\circ}$ 以

影

今 制

另 例

此夕外 $上$ 们

響

關光ナ於

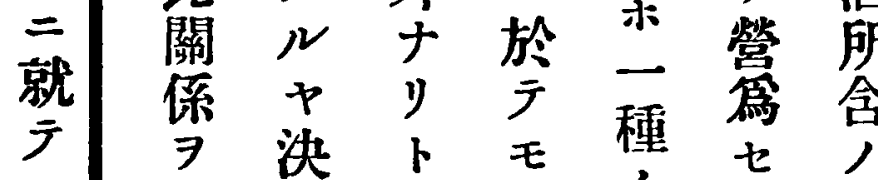

明泣踓亦少少了

テ 其記留, チ

ラ酒他 シ 質際ヤ

シ 精,,$r y=x$

×含 酒 暫 当比夕

ン有精名テ不

ガ 量 飲 後 デレゼ

第 $三$ 料白

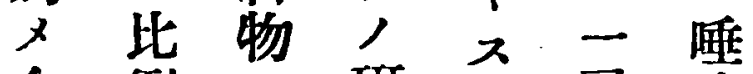

余例一研父層液

分 ス卜究1多中

所ルシ $ン$ 大,

检 者 待し人,

三人, 䖝夕, 作

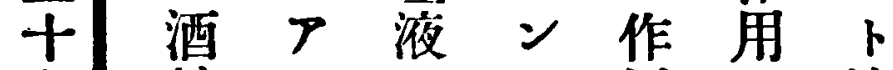

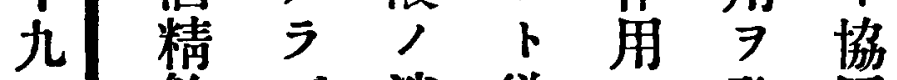

飲 ズ 消 欲 二 發同

料 必化 $\pi$ 向起澱

物 ス。 $力$ 方 粉

$=$ 是 $=$ 多 得

於诌

大向

ケ以 テ

, 力

於

實 \% 得 營 ス

二粉假處 $N$ 何㴕多

才千酒り人者卜泣大

百五二消至ナ二。

、兵 $\mathrm{ccm}$ 保化, v, 保催

是十 $\exists$ 命力 消

度 三 酒 7 化第酒力 余夕十一有度九, 如 ガ 5 分 $\mathrm{ccm}$ 入 表雨 計 ザ闑, 几實 $\mathrm{A}$ 者

算儿內消保二合各必 旦可二化命百楅自 上少消热酒宍酒單其

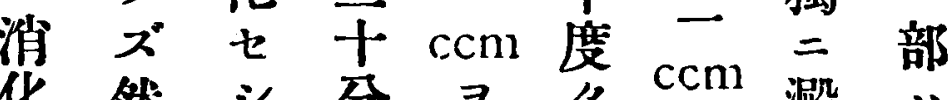
化 然 $三$ 分 7 多 ${ }^{\mathrm{ccm}}$ 澱 八 䄼ニメ二以ル附粉所 棦 $ン$ テ 文加消含 ルンセ克テ拘ス醱

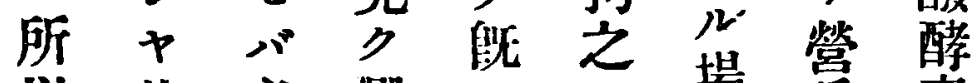
以其必澱三三場召 素 十干 $x^{*}$ 粉 三加合 ス $\%$ 其 液十 $+2=N$ 基 液二元分儿之場因 - 方 千間 二 $\operatorname{ccm} \frac{\pi}{\mathrm{ccm}} \mathrm{ccm}=$ 三觀 $=ル$ 添 添上消 广四二較疑

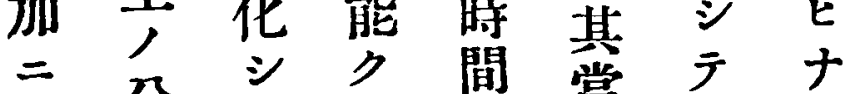
於貧得三三當詩 量 手於對算卜 モ要者五テ照以踓 既要占初照上是 二 ス 假 $\mathrm{ccm}$ ×海夜 一此定, 天液消亦 千際 澱一郎化醬 三計 百 算 $モ$ 溶 $\mathrm{ccm}$ 唾 $\exists=$ 分上液, 液逞於 十分保 $\exists$ 澱, 上 $\mathrm{ccm}$ 消 命 消 粉單 $ル$ $\Rightarrow$ 化酒化液 獨事場 


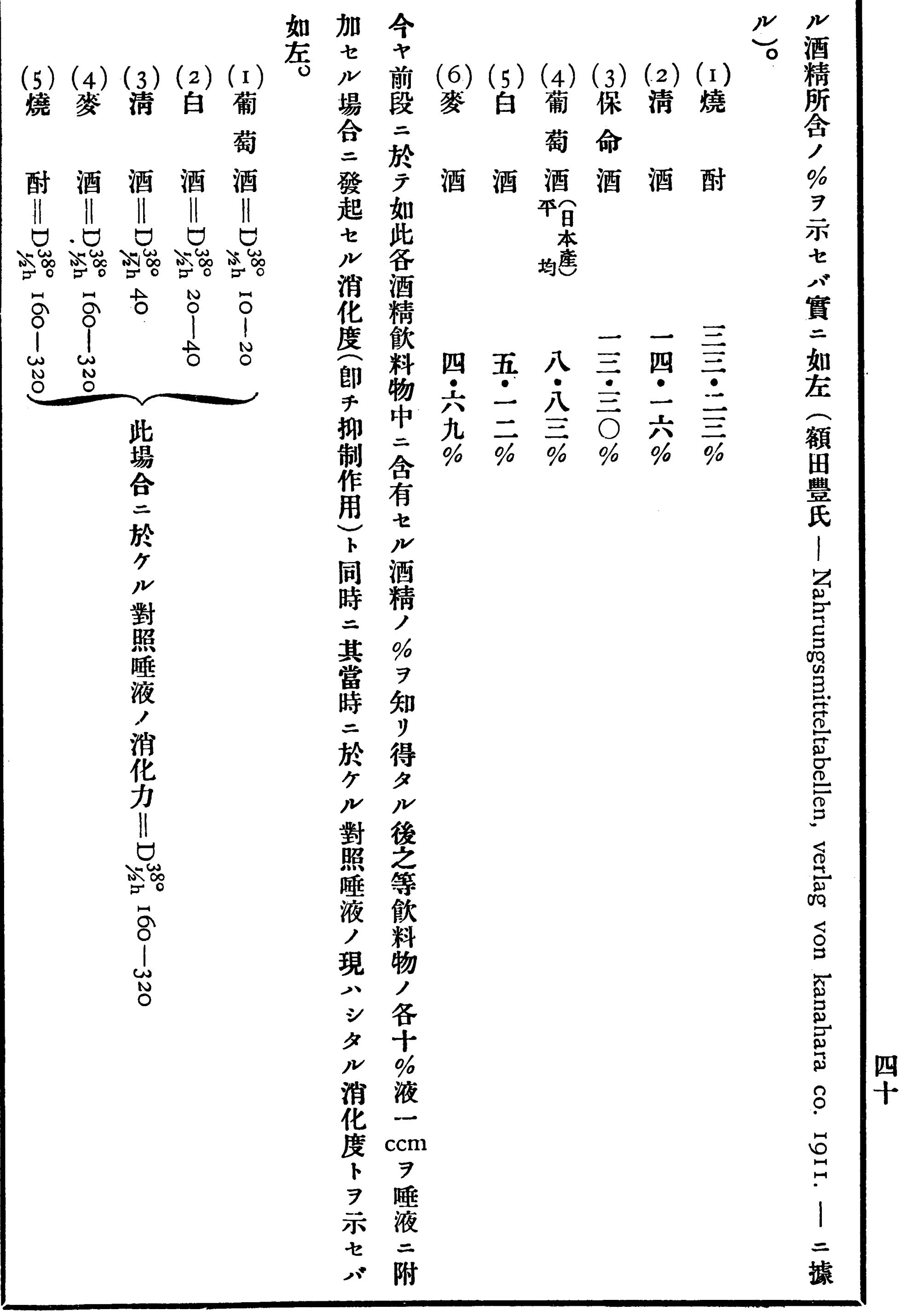




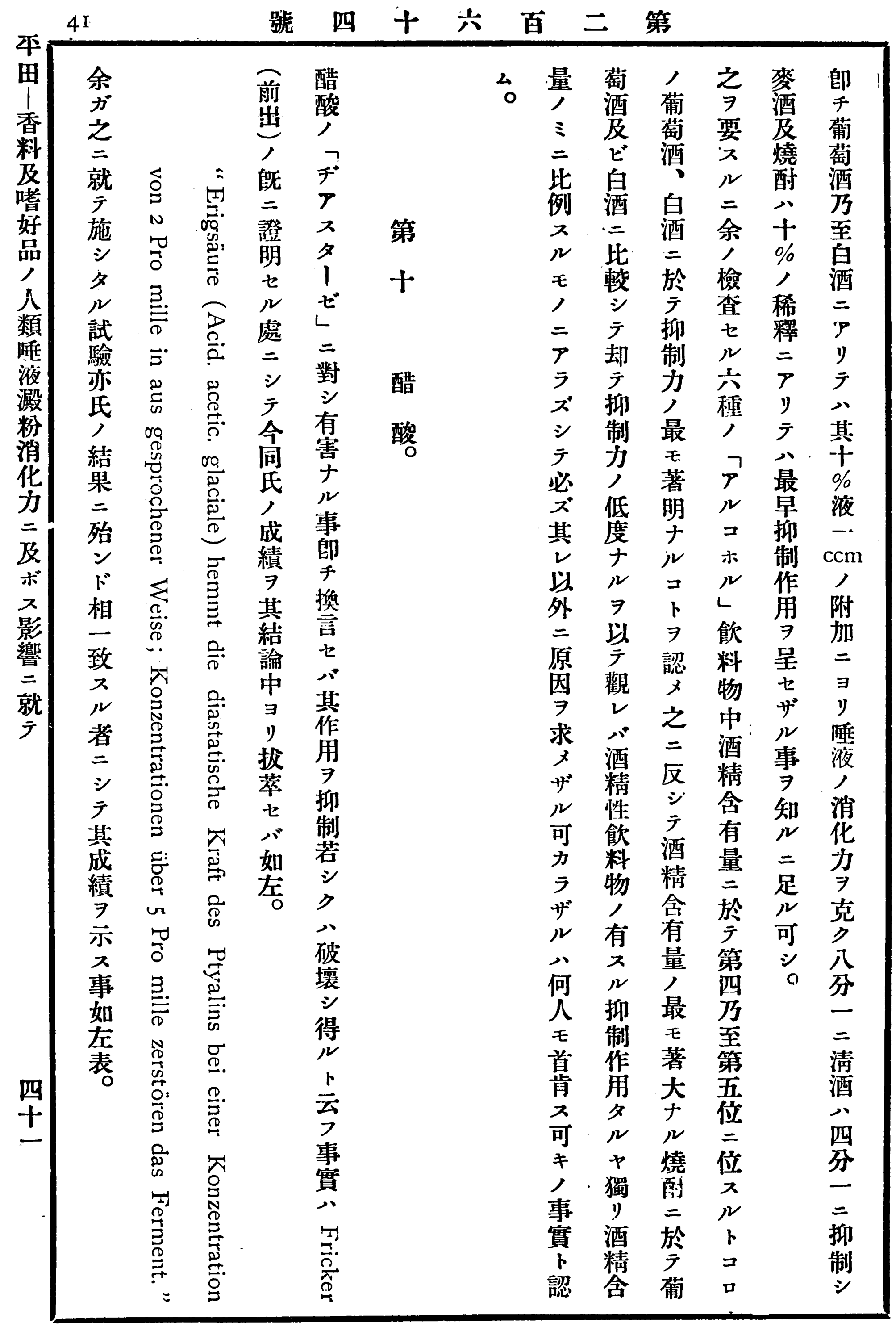




\section{號四十六百二第}

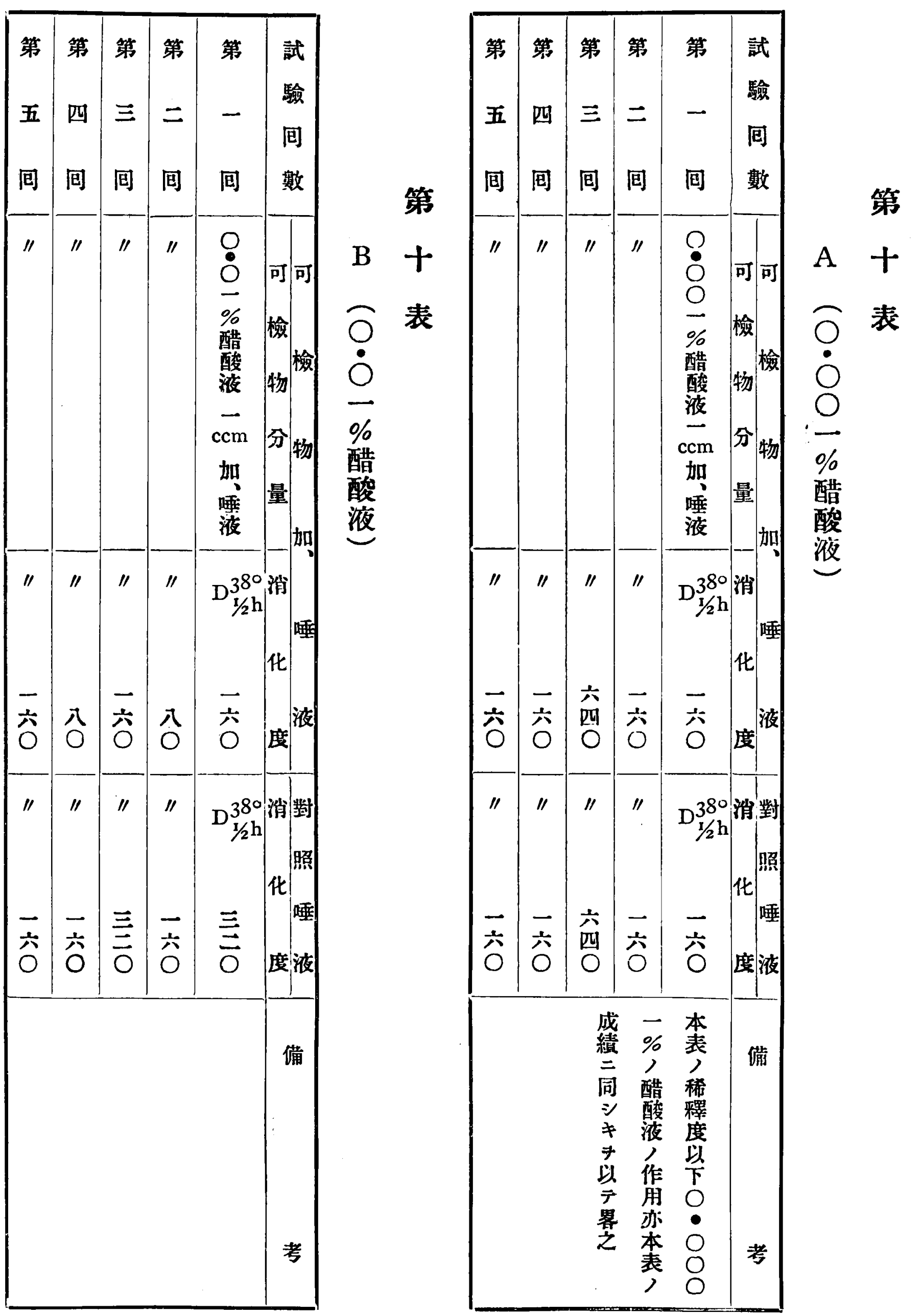


43 號 四斗六百二第

时

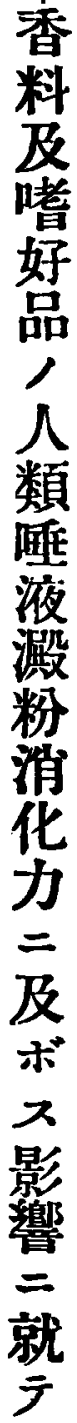

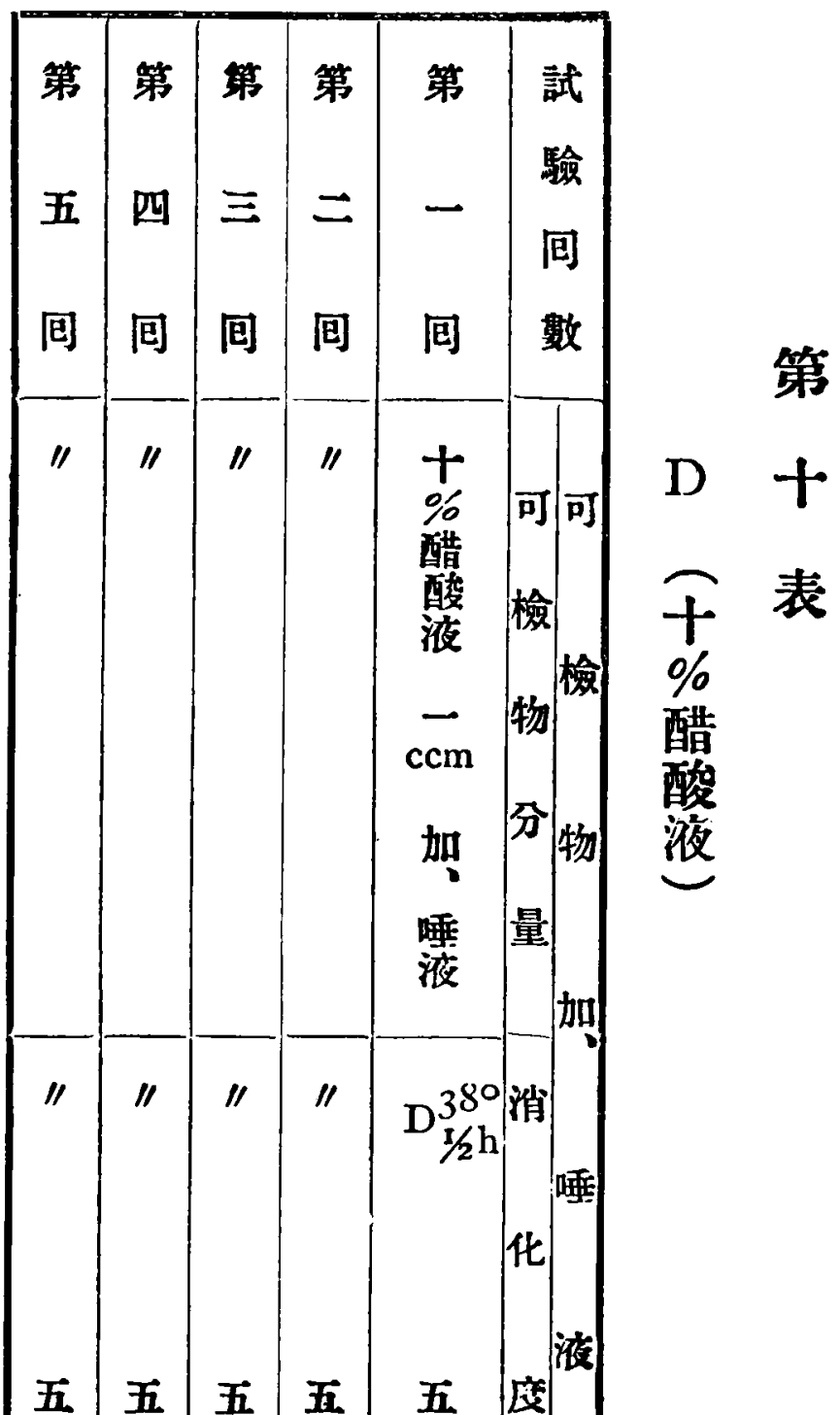

$$
\begin{aligned}
& \begin{array}{|l|l|l|l|l|l|}
\hline \text { 第 } & \text { 第 } & \text { 第 } & \text { 第 } & \text { 第 } & \text { 試 } \\
\text { 五 } & \text { 四 } & \text { 三 } & \text { 二 } & - & \text { 驗 } \\
\text { 回 } & \text { 国 } & \text { 回 } & \text { 回 } & \text { 回 } & \text { 回 } \\
\hline
\end{array} \\
& \text { ○ 可可 C 十 } \\
& \text { 醋 臉 } \widehat{\bigcirc} \text { 表 } \\
& \text { 液 物 } \\
& \text { ccm 分物 醋 } \\
& \text { 吅 量 酸 }
\end{aligned}
$$

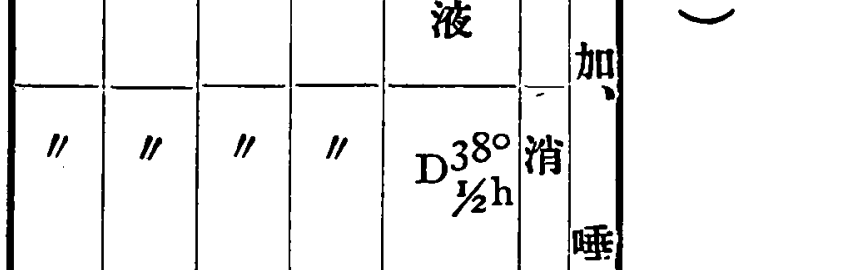

$$
\begin{aligned}
& \begin{array}{|l|l|l|l|l|l}
\text { 四 } & \text { 四 } & \text { 四 } & \text { 四 } & \text { 四 } & \text { 液 }
\end{array} \\
& \begin{array}{c|c|c|c|c|c|}
\hline \text { 六 } & \text { 六 } & \text { 六 } & \text { 亲 } & \text { 六 } & \text { 唾 } \\
\hline & 0 & 0 & 0 & 0 & \text { 液 }
\end{array}
\end{aligned}
$$

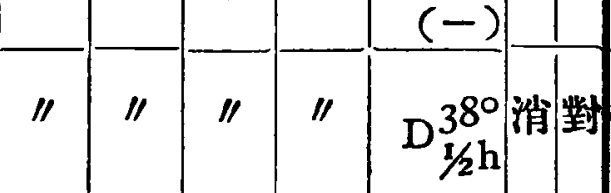$$
\text { 亲六 三 六 六 }
$$$$
\begin{array}{l|l|l|l|l|l|}
\text { 亲 } & \text { 昗 } & \text { 三 } & \text { 六 } & \text { 亲 } & \text { 度液 } \\
\hline
\end{array}
$$$$
\text { 得(一) 偨 }
$$$$
\text { (20) }
$$$$
\text { シ 此 備 }
$$$$
\text { 事 際 }
$$$$
\text { * 測 }
$$$$
\text { 意 粉 }
$$$$
\text { 味 }
$$$$
\text { 消 考 }
$$$$
\text { 化 }
$$

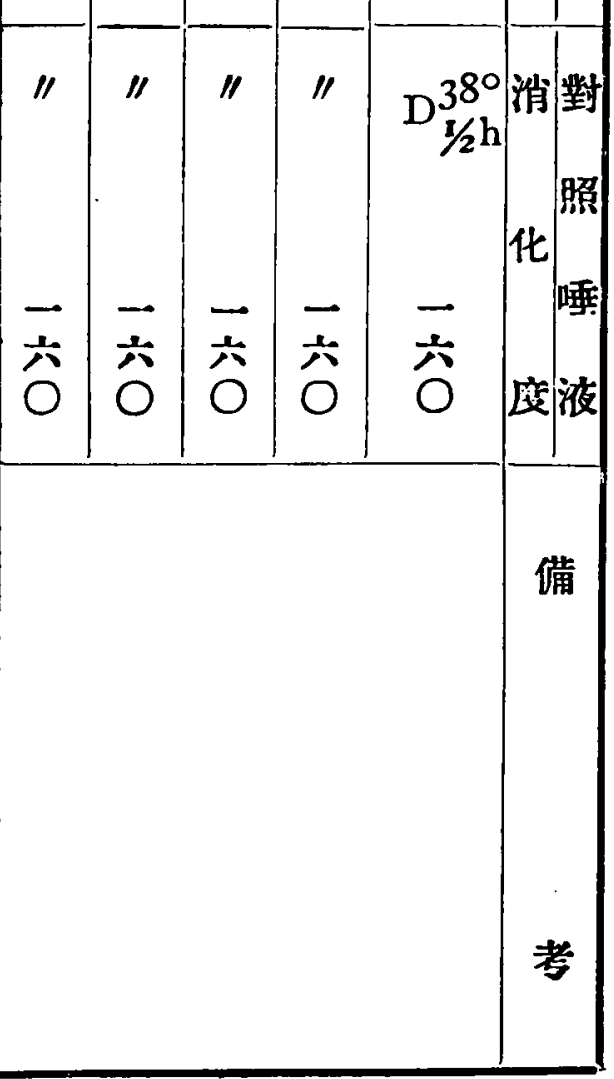


號四十六百二第

ス維

事 醀

如 酰

左

表 作

用 第 宁 7 用

關十如全,

シ - 何 然添 明

テ 二 破 加ナ

八醋 壇 $=ル$

既酸 シ 初 如

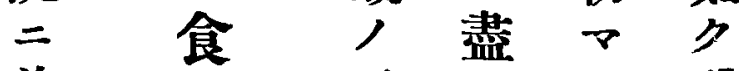
前唾スり 嚂 表酢液, 其 酸 , 0 = $=$,

表

ス

處

$=$

シ

テ

明

ナ

》

r

雖

余

續

續

テ

食

$=$

就

テ

之

試

驗

7

反

覆

シ

其

成

績

示
對ナ以偊 シ ラ上液 有 ズ漸 害 醋 次 對 ナ酸濃 ス ル,度ル 中一, 抑 $\Rightarrow \mathrm{ccm}$ 進 制 想 八 $么$ 作 像简二用 又丮隨夕 ル能七ル 二ク㿽吊 足自冬 今蒙 著 常 數明 = 十 = 强 倍純劇 量醌 量 酸 㮫 - F 液 $\mathrm{ccm}$ 其 马, 作 三 附 用 广 加 夕 其 $=ル$ キ 既 $7 \overline{\text { 二 }}$ 破 壤 優 ・ 政 0 得 唩 -

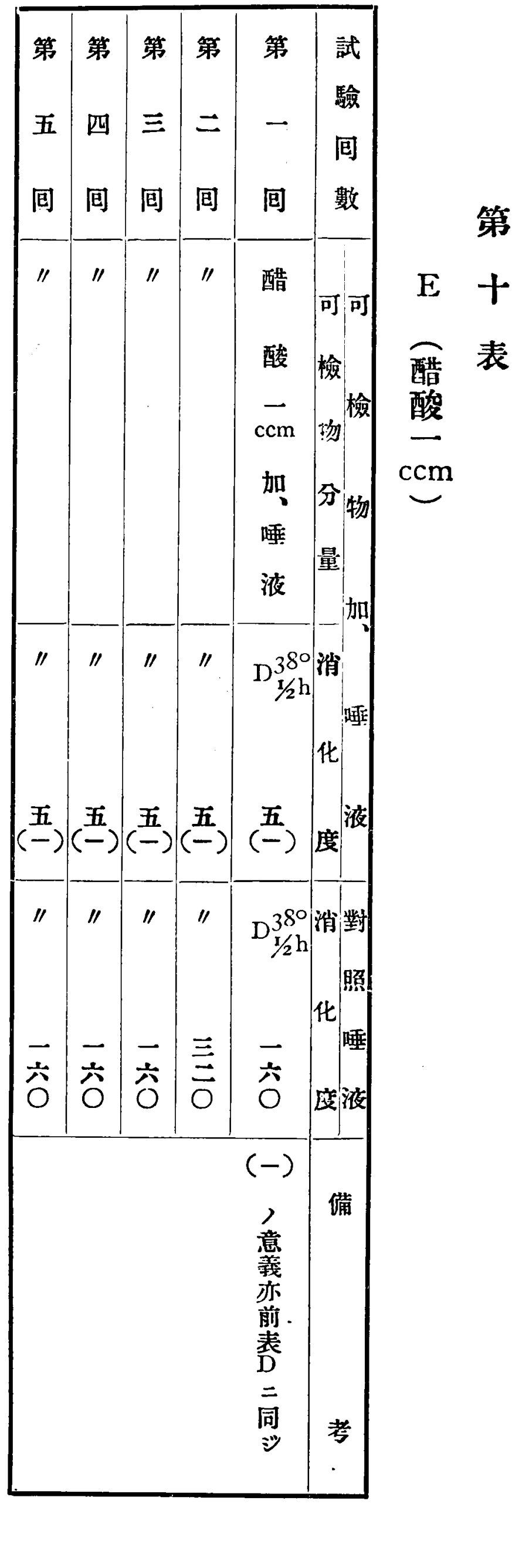




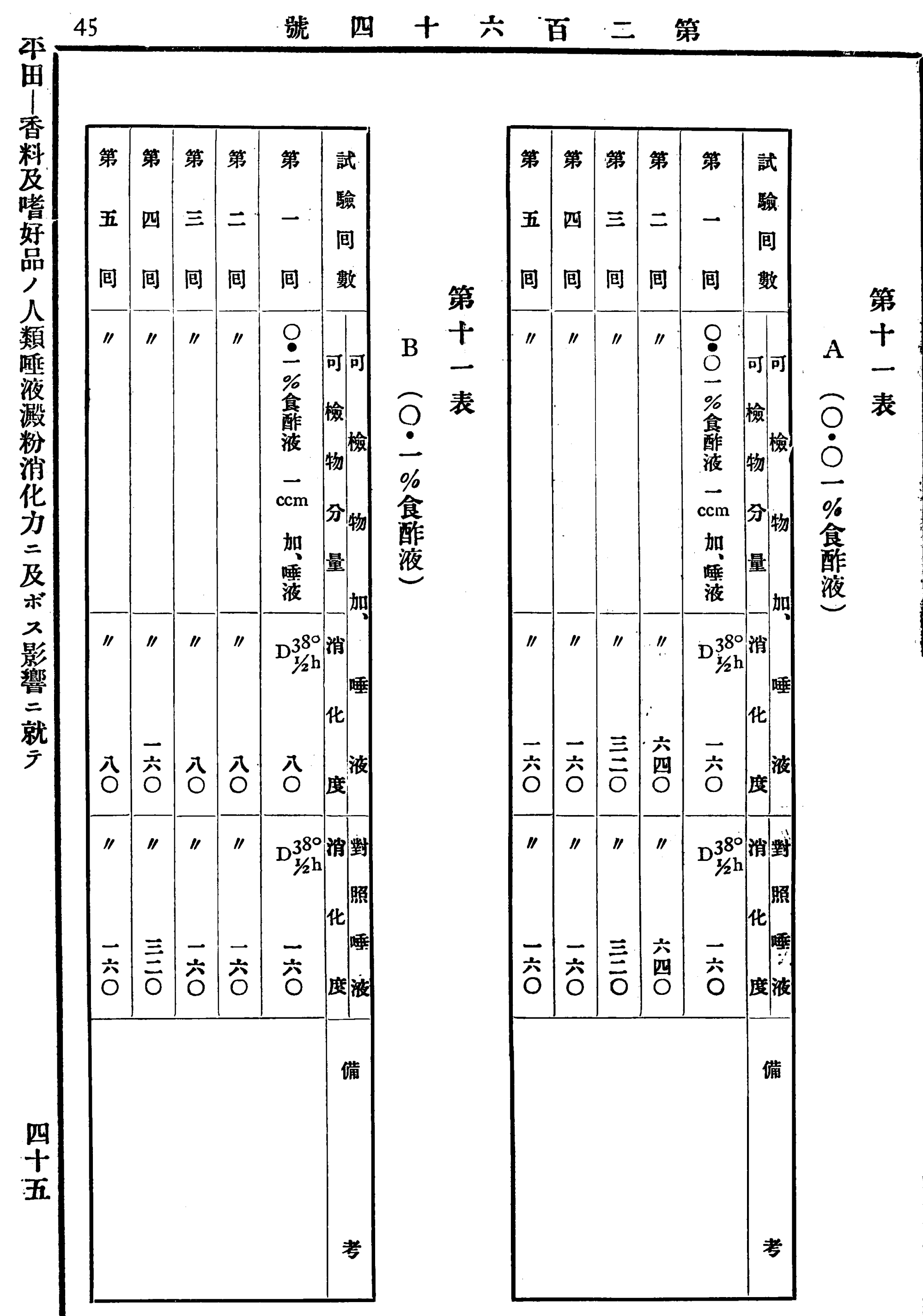


號四十六百二第

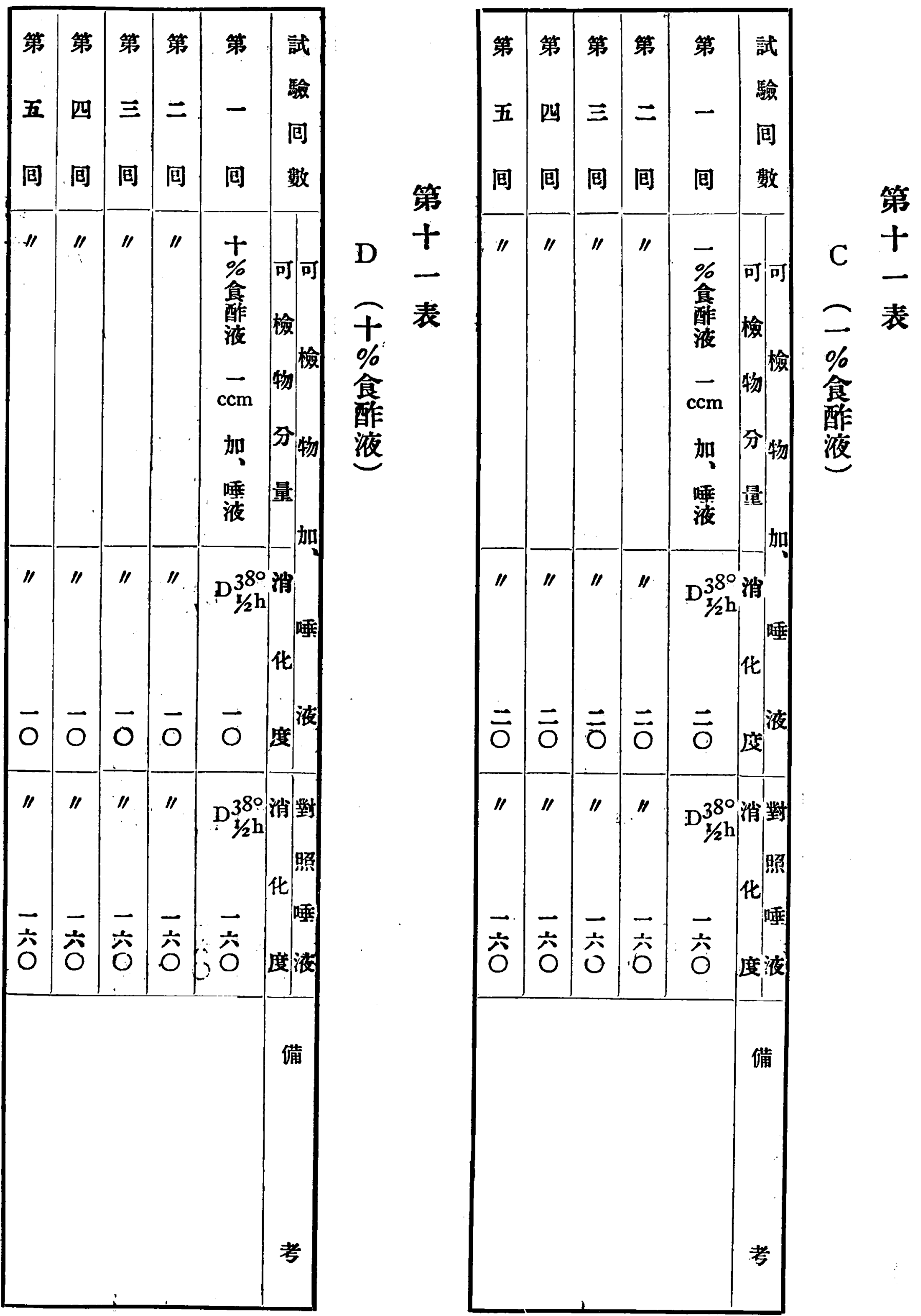


田 = 依

替堪 学

料 ザ之

及 》其

喷 シ 種

好

品以品

人類我

ガ

曙地り, 三人, 茶

腹 方 $三$ 間 製 品 素

澱

粉

消

华

及

及

ホ、ラ 見

影 $\%$ 事

響 ・素

$=>\quad \exists$

就 $心$, 》

某明

-

種 y

$\exists$ r

選 雖

.ン 余

デ ハ

陚 多

羷 數

, ,

用 種

二 類

供

四

七 涉

t

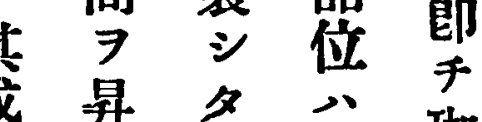

ル. y

者 之
鞦 シ 製 $テ$ 間 酸夕 垔示其三晚葉 甚

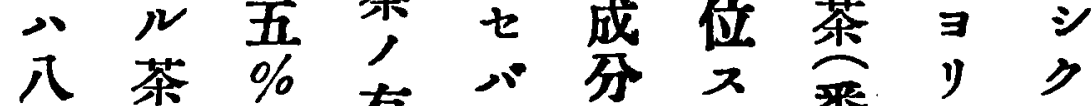

シ 檢

テ 查

郎

于

余,

八煩

卜類 噮 茶
成 シノ = 至 其

分隨中

一 碓

亦

稀 强

釋 度

$=$,

達 抑

シ. 制

テ 作

初用

× 7

亦济大

二 其 日 是體

卜種本走 二

素類三ナ之

旗於り

リルケ甲區

免多ル心别

レク 一 本 シ

ザ 殊 般 邦 テ

$ル=$ 家固二

處同庭有種

ナ二, , ト

り種食煎ナ

雖 $==\equiv$ 可

今 $>$ 離 シ ク

試りルテ師

二广可所 千

梅モカ 謂 新

村：產三綠、芽

氏 地ザ余

二、ル之主

據製處三製

少法

梅人者文夕

梅異郎乙

村同千公者

甚二是甲质

态㮣 稍

郎济ナ比仡

新方少 $九$ 後

犁各上レ次

撰自公必

食基尚遥为

厂 唾

茶其 液

作 =

用 向

$\Rightarrow \overline{7}$

失 發

フ 起

者

上

ス 事

○ 前、

表

既

$=$

示

잦

處

$=$

i

广

其

濃

度

淮

出

$=$

隨

飞

篮

々

著

明

植颚桀三處

物 $\Rightarrow$ 上 等 軟

誌 異一卡等，軟 
號 四十六百二第

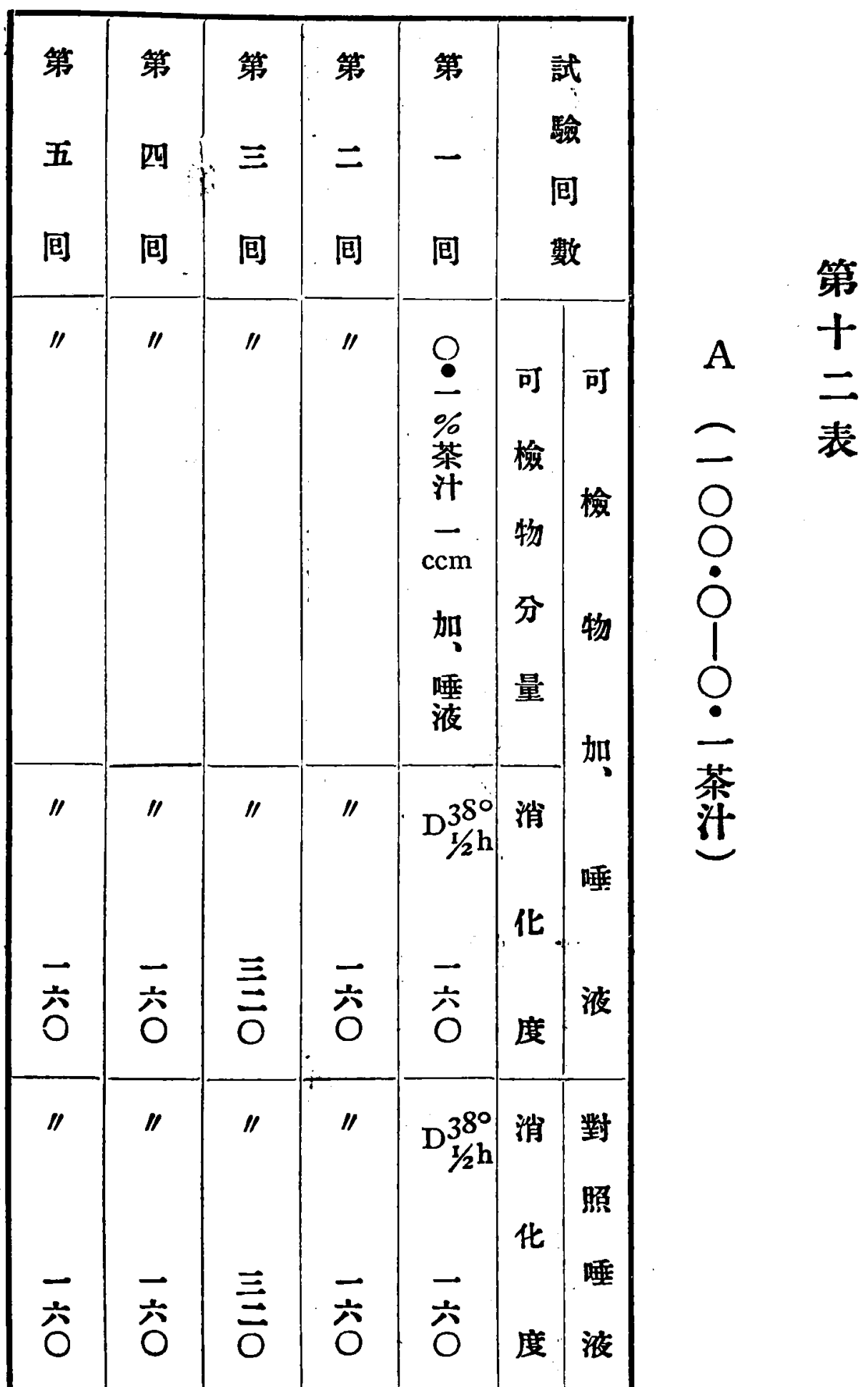

婪 $\bigcirc$ 先

表中左

二表

$+=$

分 揭

時 ろ゙

煮 タ

沸

煎 ガ

出 如

七 $\neq$

ハ 種

者 \&

r

万分

量

後 $=$

于 於

ב $\bar{~}$

ᄂ

$\exists \quad$

濾 ガ

過 煎

シ 汁

以 7

今 製

得

タ

假

濾命

汗

$\Rightarrow$ 表

檢中

香 -

, \%

用

$=\gamma$

備

供

シ

夕 茶

ㄴ-

者

$=\quad$

シ 蒸

于 餾

其 水

成 -

績 $\mathrm{O}$ 


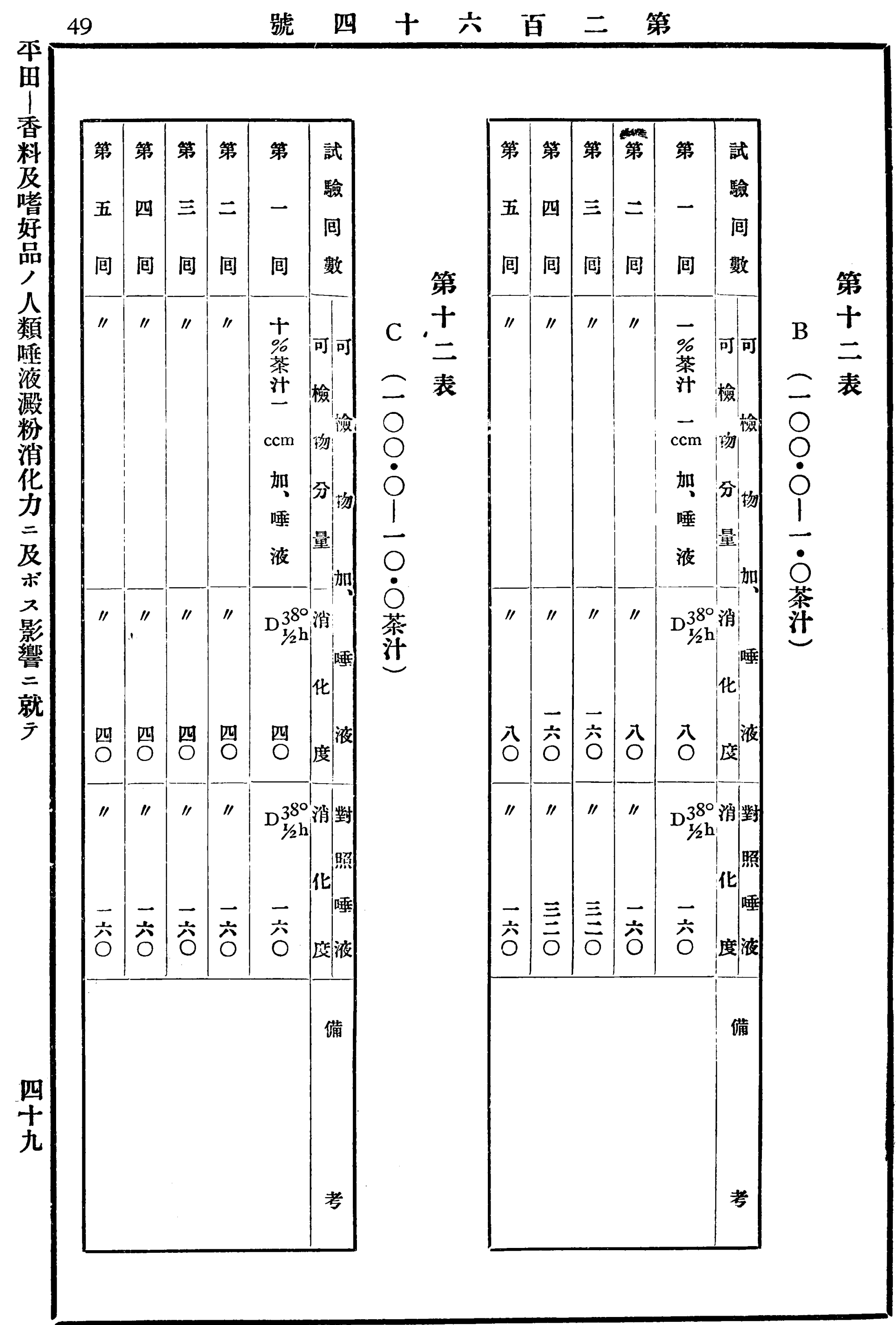


號四十宍百二第

水 二其通 落

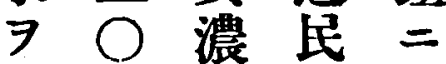

用 ○度間揭

七 ○各二分

テ $\dot{0}$ 自於夕

煎

出 I家食處

滀庭事人士制大通ス

回间间间间数

シ抑ナ表

初制少,

メ华 ガ 成

其 亦 $=$

第 抑 强 普 照
十 命差都類

三ル郎度认

濾罟 2 必前

腋一公揭

試 $\%$ 素用

試 $\% 0, \exists 工$ 程

驗煎贫所類

目染免所比

的, ザ我 ス

二比ルガ

供例·處地心

用二ナ方 趣

シ 煎り $=$ 习

結出卜广異

果七踓 ᄀ二

$\exists ル$ 余心

示モ ガン

入, 家茶,

事、庭 ᄂ 最

如如, 下南

左平臺稳 等

$\Rightarrow$ 處 $ᄌ$ 品

以 $=ル 2$

应於粗

余 惡 事

八朝品八

此夕二䠶

比常 $シ=$

例 用于述

$=$ 女其心

於儿有夕

广分效 ル

之量成處

$\Rightarrow$ 分 $=$

+ 亦

分厂少

間 八量 郎

飲本占于

用均 又普
達其者本

广用故 績

作 ナ吾二

用儿人本

$\exists=カ^{*}$ 品

失 卜、契

晚 ス 7 茶 實

茶 ル想用二

者像卜唾:

卜

スル

二日作

足 常 用

使 7

可 角抑

万ス制

喫ルシ

茶處 得

用人

卜程 者

渡二

テ, シ

殆濃 テ

ド厚之

見 $=$ V

㑊

可り其

力テ 分

ラ 八量

ザ

ル 恐比

人例

稀 哭

釋筫 テ

度 等 抑

師寺制

チ学力

$\overline{\%}$ 此

紫例

汁 留

$=$ テ 


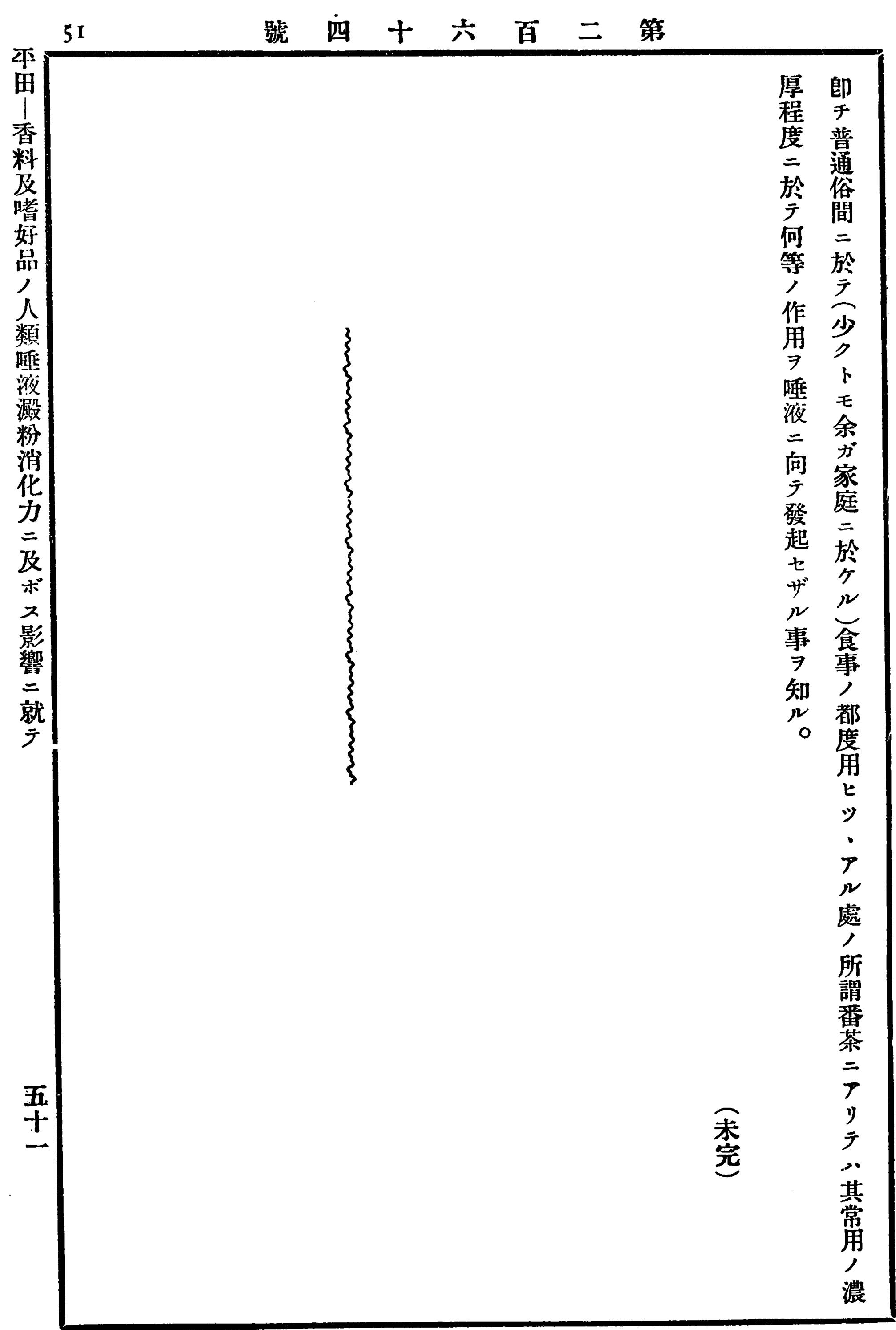

